Pacific Northwest National Laboratory

Operated by Battelle for the U.S. Department of Energy

Under Contract DE-AC05-76RL01830

\title{
Optimization of Concurrent Deployments of the Juvenile Salmon Acoustic Telemetry System and Other Hydroacoustic Equipment at John Day Dam
}

\begin{abstract}
GR Ploskey
JS Hughes

F Khan

J Kim

B LaMarche
\end{abstract}

GE Johnson

E Choi

DM Faber

M Wilberding

D Deng
MA Weiland

SA Zimmerman

E Fischer

A Cushing

September 2008

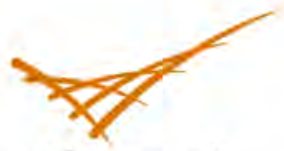

Pacific Northwest NATIONAL LABORATORY 


\title{
DISCLAIMER
}

This report was prepared as an account of work sponsored by an agency of the United States Government. Neither the United States Government nor any agency thereof, nor Battelle Memorial Institute, nor any of their employees, makes any warranty, express or implied, or assumes any legal liability or responsibility for the accuracy, completeness, or usefulness of any information, apparatus, product, or process disclosed, or represents that its use would not infringe privately owned rights. Reference herein to any specific commercial product, process, or service by trade name, trademark, manufacturer, or otherwise does not necessarily constitute or imply its endorsement, recommendation, or favoring by the United States Government or any agency thereof, or Battelle Memorial Institute. The views and opinions of authors expressed herein do not necessarily state or reflect those of the United States Government or any agency thereof.

\author{
PACIFIC NORTHWEST NATIONAL LABORATORY \\ operated by \\ BATTELLE \\ for the \\ UNITED STATES DEPARTMENT OF ENERGY \\ under Contract DE-AC05-76RL01830
}

Printed in the United States of America
Available to DOE and DOE contractors from the
Office of Scientific and Technical Information,
P.O. Box 62, Oak Ridge, TN 37831-0062;
ph: (865) 576-8401
fax: (865) 576-5728
email: reports@adonis.osti.gov

\author{
Available to the public from the National Technical Information Service, \\ U.S. Department of Commerce, 5285 Port Royal Rd., Springfield, VA 22161 \\ ph: (800) 553-6847 \\ fax: (703) 605-6900 \\ email: orders@ntis.fedworld.gov \\ online ordering: http://www.ntis.gov/ordering.htm
}

This document was printed on recycled paper. 


\section{Optimization of Concurrent Deployments of the Juvenile Salmon Acoustic Telemetry System and Other Hydroacoustic Equipment at John Day Dam}

$\begin{array}{lll}\text { GR Ploskey } & \text { GE Johnson } & \text { MA Weiland } \\ \text { JS Hughes } & \text { E Choi } & \text { SA Zimmerman } \\ \text { F Khan } & \text { DM Faber } & \text { E Fischer } \\ \text { J Kim } & \text { M Wilberding } & \text { A Cushing } \\ \text { B LaMarche } & \text { D Deng } & \end{array}$

September 2008

Prepared for

U.S. Army Corps of Engineers, Portland District

Portland, Oregon 97208

Pacific Northwest National Laboratory

Richland, Washington 99352 



\section{Summary}

This report documents the results of an acoustic optimization study conducted by the Pacific Northwest National Laboratory (PNNL) for the U.S. Army Corps of Engineers Portland District (USACE) at John Day Dam during January and February 2008. The goal of the study was to optimize performance of the Juvenile Salmon Acoustic Telemetry System (JSATS) by determining deployment and data acquisition methods that minimized electrical and acoustic interference from various other hydroacoustic sampling devices. Optimization of JSATS performance, if successful, would allow concurrent sampling by active and passive acoustic methods during formal evaluations of the prototype surface flow outlets at the dam during spring and summer outmigration seasons for juvenile salmonids. The objectives for the optimization study at John Day Dam were to:

1. Design and test prototypes and provide a total list of pipes and trolleys needed to deploy JSATS hydrophones on the forebay face of the powerhouse and spillway for the formal 2008 evaluation.

2. With JSATS tags arrayed in the forebay and detected on the dam-face hydrophones, assess the effect on the JSATS data from turbine unit and spillway flows and operations of a dual frequency identification sonar (DIDSON), an acoustic Doppler current profiler (ADCP), and a fixed-aspect, Precision Acoustic Systems (PAS) hydroacoustic system.

3. Determine the relationship between fixed-aspect hydroacoustic transmit level and mean percentage of JSATS tag transmissions decoded.

The general approach was to use hydrophones to listen for transmissions from JSATS tags deployed in vertical arrays in a series perpendicular to the face of the dam. PNNL used two acoustic telemetry systems for the testing; the JSATS dam face cable array and a system manufactured by Teknologic LLC. In addition, we assessed two versions of the JSATS signal detector and decoder software, as well as two different types of hydrophone baffling. The optimization study consisted of a suite of off/on tests. The primary response variable was mean percentage of decoded JSATS tag transmissions.

PNNL found that there was no appreciable adverse effect on mean percentage decoded for JSATS transmitters from turbine operations; spillway operations; DIDSON/ADCP acoustic energy; and Precision Acoustic Systems (PAS) hydroacoustic systems at a transmit level of $-12 \mathrm{~dB}$, although there was a significant impact at all higher transmit levels ( -11 to $-6 \mathrm{~dB})$.

The main conclusion from this optimization study is that valid JSATS telemetry data can be collected simultaneously with a DIDSON/ADCP and a PAS hydroacoustic system at transmit level -12 dB.

Multiple evaluation tools should be considered to increase the robustness and thoroughness of future fish passage evaluations at John Day and other dams. 



\section{Preface}

This study was funded to support the evaluation of the top spillway weir (TSW) at John Day Dam during 2008 as part of the U.S. Army Corps of Engineers' (USACE's) Anadromous Fish Evaluation Program (AFEP). The TSW evaluation has AFEP Study Code SPE-P-08-3. The study was conducted by the Pacific Northwest National Laboratory (PNNL) for the USACE Portland District, whose technical lead was Robert Wertheimer (503 808 4777). The PNNL technical leads were Gene Ploskey (509 427 9500), Mark Weiland (509 427 5923), and Gary Johnson (503 417 7567). This report constitutes the final deliverable for this project (PNNL project No. 54040). 



\section{Acknowledgments}

The authors are thankful to all who contributed to this study, including:

- USACE personnel at John Day Dam: Bob Cordie, Miro Zyndol, and Operations, Structural, and Electrical personnel;

- USACE personnel at the Portland District: Mike Langeslay, Bob Wertheimer;

- Honald Crane Services: Bob Austin Mike Honald;

- PNNL: Tom Carlson, Dennis Dauble, Susan Ennor, Julie Hughes, Mike Parker, Tom Seim;

- Precision Acoustic Systems: Alan Wirtz;

- Teknologic LLC: Bill Beatty, George Diefenbach;

- The Dalles Iron Works;

- Divers: Global Diving and Salvage, U.S. Army Divers. 



\section{Acronyms and Abbreviations}

$\begin{array}{ll}\text { 2-D } & \text { two-dimensional } \\ \text { 3-D } & \text { three-dimensional } \\ \text { ADCP } & \text { acoustic Doppler current profiler } \\ \text { AFEP } & \text { Anadromous Fish Evaluation Program } \\ \text { C } & \text { centigrade } \\ \text { dB } & \text { decibel(s) } \\ \text { DIDSON } & \text { dual frequency identification sonar } \\ \text { El } & \text { elevation } \\ \text { ft } & \text { foot/feet } \\ \text { HA } & \text { hydroacoustic(s) } \\ \text { in. } & \text { inch(es) } \\ \text { JDA } & \text { John Day Dam } \\ \text { JSATS } & \text { Juvenile Salmon Acoustic Telemetry System } \\ \text { kcfs } & \text { 1000 cubic feet per second } \\ \text { kHz } & \text { kiloHertz } \\ \text { lb } & \text { pound(s) } \\ \text { m } & \text { meter(s) } \\ \text { MPD } & \text { mean percentage of decoded transmissions } \\ \text { MW } & \text { megawatt } \\ \text { NA } & \text { not applicable } \\ \text { PAS } & \text { Precision Acoustic Systems } \\ \text { PNNL } & \text { Pacific Northwest National Laboratory } \\ \text { Pps } & \text { pings per second } \\ \text { ROV } & \text { remote operated vehicle } \\ \text { SC } & \text { Sonic Concepts } \\ \text { TSW } & \text { top spillway weir } \\ \mu \text { Pa } & \text { micro-Pascals } \\ \text { USACE } & \text { U.S. Army Corps of Engineers } \\ & \end{array}$





\section{Contents}

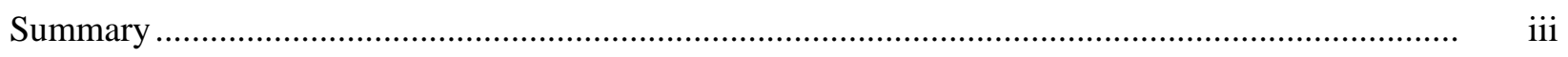

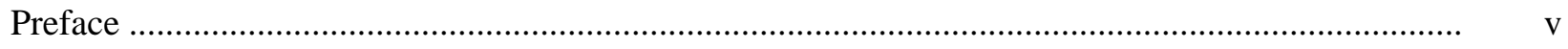

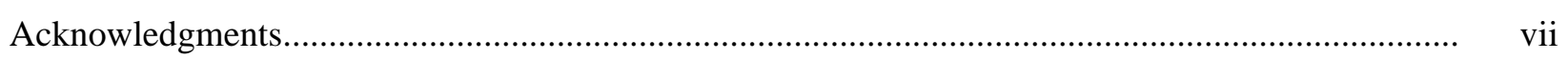

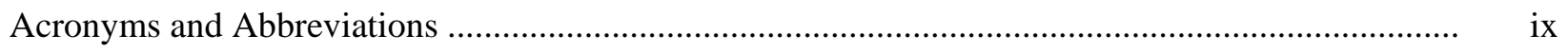

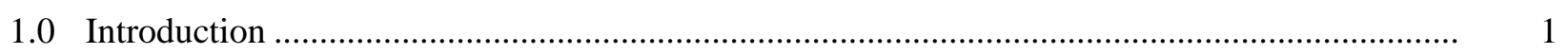

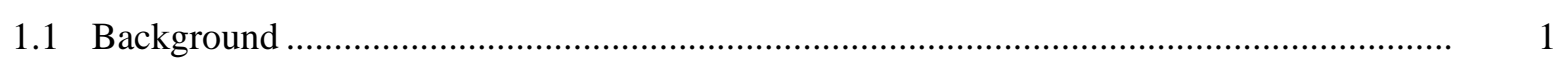

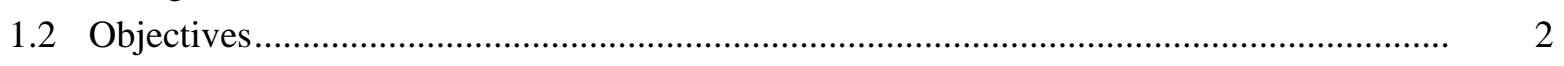

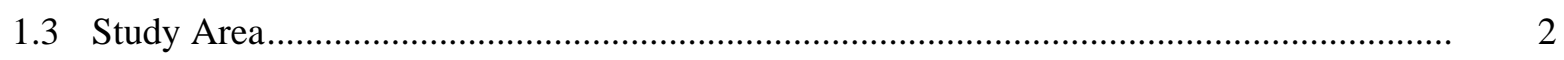

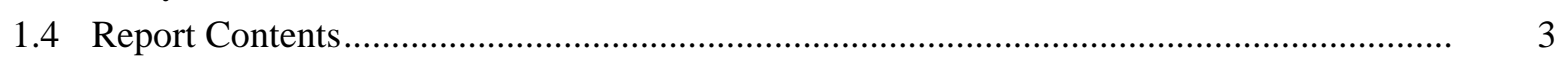

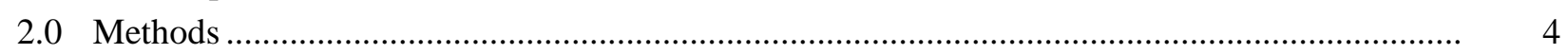

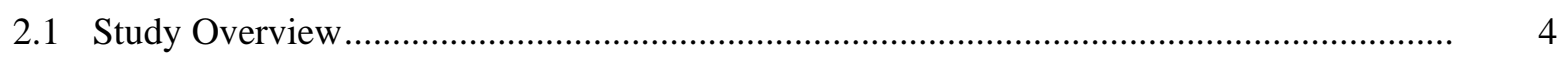

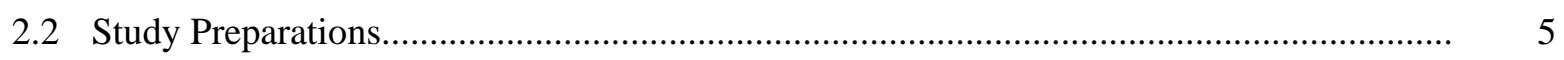

2.2.1 Pipes and Trolleys for Hydrophones ................................................................ 5

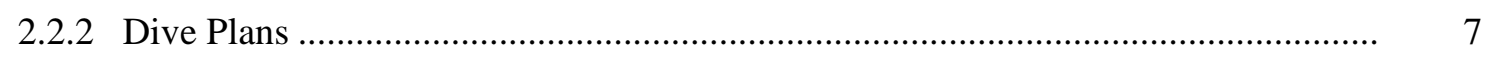

2.2.3 Preliminary Tests in the Laboratory .................................................................. 7

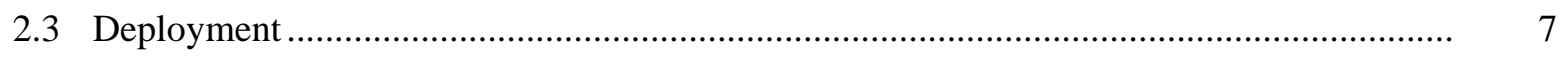

2.3.1 PAS Hydroacoustic Transducer Locations............................................................ 7

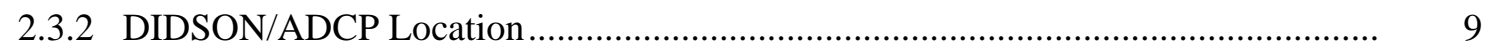

2.3.3 Electronics and Acoustic Telemetry Hydrophones .............................................. 10

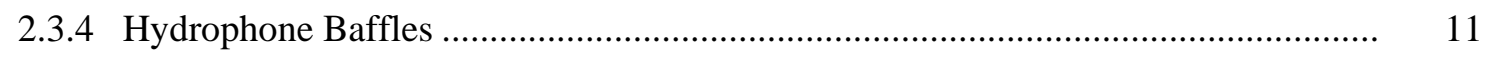

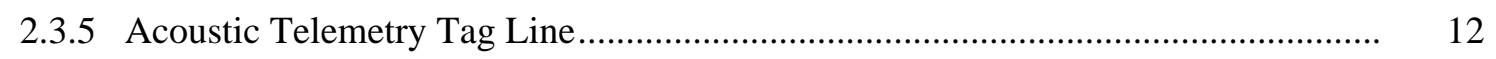

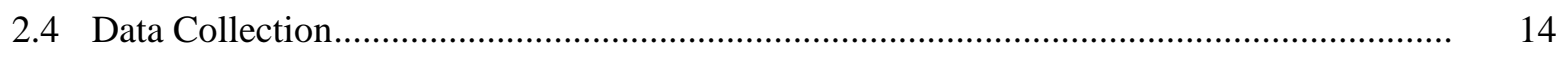

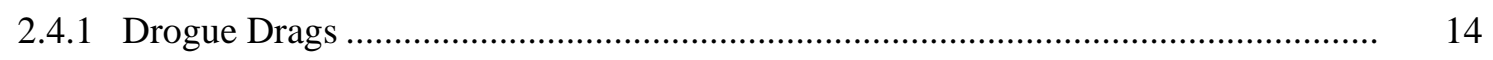

2.4.2 Testing Effects of Hydroacoustic Transmission Level ........................................... 14

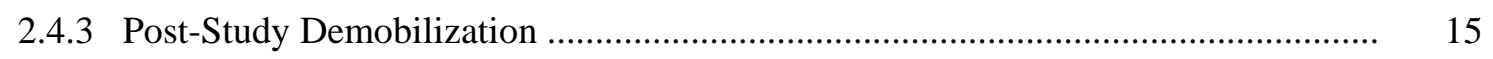

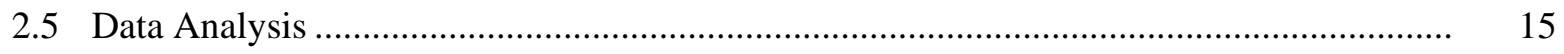

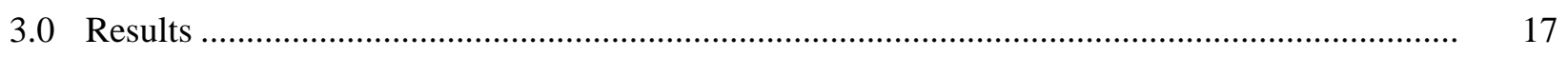

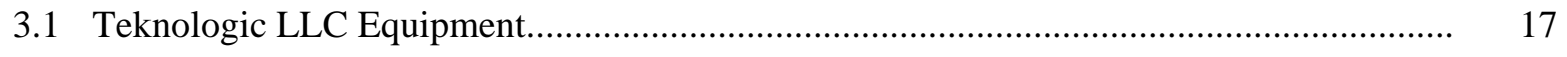

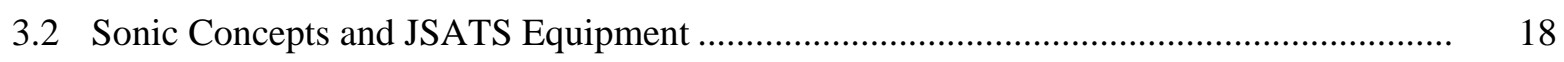

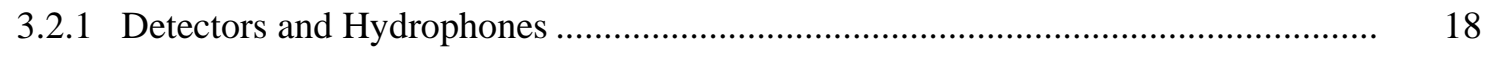

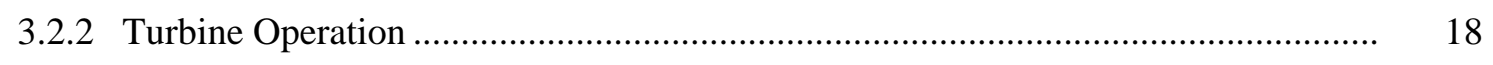

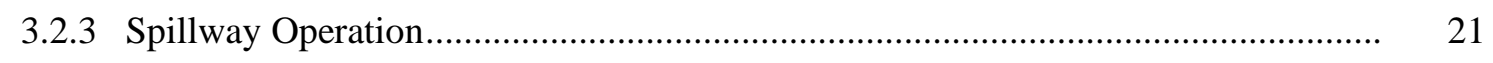

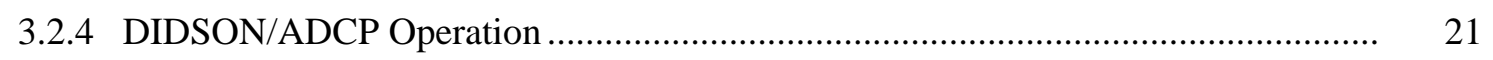

3.2.5 PAS Hydroacoustic System Operation................................................................. 22

3.2.6 PAS Hydroacoustic System Transmit Level ......................................................... 24

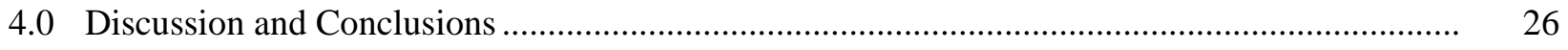

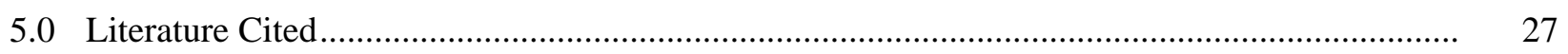




\section{Figures}

1.1 Plan Diagram of John Day Dam with Boxes Highlighting Study Sites and Frontal Views of Specific Study Areas.

2.1 Front Views of Generic Hydrophone Locations at a Turbine Unit and Spill Bays at John Day Dam.

2.2 Pipe with Funnel for Acoustic Telemetry Trolley and Hydrophone Attached to a Powerhouse Pier-Nose at John Day Dam.

2.3 Turbine Cross Section Showing a Single Hydroacoustic Beam for a Transducer Sampling Guided Fish Passing Above a Submersible Traveling Screen..

2.4 Cross-Sectional View of a Spill Bay Showing a Hydroacoustic Beam Deployed Just Below the Water's Surface and Aimed Slightly Downstream Off of Vertical.....

2.5 Cross-Sectional View of a Spill Bay with a Top Spillway Weir and the Proposed Aiming Angle for Three Split-Beam Transducers and a Front View of the Same TSW Bay

Showing the Split Beams.

2.6 Photographs of a Trolley/Rotator Package for Deploying the DIDSON and ADCP and the Loaded Trolley Being Lowered Down a 4-by-4-in. Box Beam at The Dalles Dam.

2.7 Plan View of a Generic DIDSON/ADCP Deployment Showing Sampling Zones Covered by Rotating the Aiming Angle of the Instruments.

2.8 Diagram Illustrating the Location of JSATS Hydrophones on the Main Piers in Side View and in Frontal View

2.9 Front View Illustrating the Approximate Location of JSATS Hydrophones on Main Spillway Piers 16/17, 17/18, and 18/19.

2.10 Photographs of the Plywood Baffle and the Anechoic Baffle

2.11 Tag Line with a Series of Vertical Arrays of JSATS Transmitters

2.12 Tag Line Deployed Upstream of Pier 15/16 at the Powerhouse and Upstream of Spillway Pier $17 / 18$.

3.1 Mean Percentage Decoded by Range for Individual JSATS Transmitters Arrayed in the Spillway Forebay of John Day Dam, January and February 2008 - Teknologic LLC Equipment.

3.2 Summary Data from Teknologic LLC Detector and Decoder.

3.3 Mean Percentage Detected by Range for the Four Combinations of Old and New Detectors and 180- and 22-Degree Sonic Concepts Hydrophones

3.4 Turbine Operation Effects on Mean Percentage Decoded by Range for Individual JSATS Transmitters Arrayed in the Turbine 14/15 Forebay of John Day Dam, January and February 2008 - JSATS “Mobile” Hydrophone, Old Detector, Plywood Baffle.

3.5 Spillway Operation Effects on Mean Percentage Decoded - Old Detector, Plywood Baffle...

3.6 DIDSON/ADCP Operation Effects on Mean Percentage Decoded by Range for Individual JSATS Transmitters Arrayed in the Spillway Forebay of John Day Dam, January and February 2008 - Old Detector, Plywood Baffle

3.7 PAS Hydroacoustic System Operations, DIDSON/ADCP Off, Plywood Baffle

3.8 Summary Data from JSATS Mobile Node, Sonics Concepts Hydrophones with JSATS Detectors and Decoders. 
3.9 Relationship Between Mean Percentage Decoded and PAS Hydroacoustic Transmit Level ... 24

3.10 Relationship Between MPD and PAS Hydroacoustic Transmit Level................................... 25

\section{Tables}

2.1 General Test Treatments for the Acoustic Optimization Study at John Day Dam, January

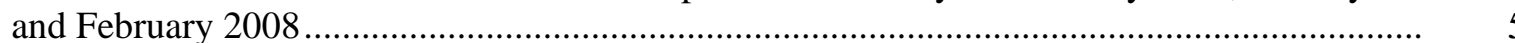

2.2 Relevant Specifications for the Acoustic Systems ................................................................ 



\subsection{Introduction}

This report documents the results of an acoustic optimization study conducted by the Pacific Northwest National Laboratory (PNNL) for the U.S. Army Corps of Engineers Portland District (USACE) at John Day Dam during January and February 2008. The goal of the study was to optimize performance of the Juvenile Salmon Acoustic Telemetry System (JSATS) by determining deployment and data acquisition methods that minimized electrical and acoustic interference from various other hydroacoustic sampling devices. Optimization of JSATS performance, if successful, would allow concurrent sampling by active and passive acoustic methods during formal evaluations of the prototype surface flow outlets at the dam during spring and summer outmigration seasons for juvenile salmonids.

\subsection{Background}

During planning in fall 2007, the USACE considered using a combination of fixed-aspect hydroacoustics, dual frequency identification sonar (DIDSON), acoustic Doppler current profiler (ADCP), and juvenile salmon acoustic telemetry system (JSATS) to evaluate the performance of top spill weir (TSW) prototype surface flow outlets to pass juvenile salmonids at John Day Dam (JDA). In preparation for the 2008 and subsequent evaluations, the USACE funded the optimization study reported herein to identify and alleviate interference between acoustic sampling methods, all of which use underwater sound to quantify fish passage and behavior. Such a study was needed to assure managers that among-gear interference could be minimized and that the acoustic telemetry study would not be compromised by other acoustic sampling methods. The intent was to help ensure that the 2008 TSW evaluation would provide the best possible information to support management decisions.

Different acoustic systems can interfere with one another, if they are not properly deployed or if acquisition and processing are not carefully designed to minimize interference. Fixed hydroacoustics are compatible with the ADCP and DIDSON (Ploskey et al. 2005). The primary concern in our study was interference of fixed-aspect hydroacoustic, DIDSON, and ADCP transmissions on detection and decoding of transmissions from JSATS tags. Before this study, JSATS equipment had not been operated concurrently in the same area with other acoustic systems. Interference by these other sampling tools can come from electrical or acoustic sources. Electrically impulsive crosstalk can occur if cables are adjacent to each other and shielding is not adequate. This type of interference is relatively easy to diagnose and remedy. Acoustic interference from detections of sounds transmitted by other equipment depends upon the degree of overlap in frequency and the nature of each transmitted sound. The $420-\mathrm{kHz}$ frequency of the USACE's Precision Acoustic Systems (PAS) hydroacoustic transducers is very close to the average 416.5-kHz frequency that JSATS tags transmit, although the signals are fundamentally different. The JSATS acoustic tags transmit a 31-bit binary coded pulse once every 3 to 10 seconds, depending on user selectable transmission rates. Fixed location hydroacoustics systems will transmit 20 to 30 pulses of sound per second at high amplitude (>200 dB $\| 1 \mu \mathrm{Pa}$ at $1 \mathrm{~m}$ ).

During spring and summer 2008, the USACE evaluated two prototype surface flow outlets at the JDA spillway using acoustic telemetry. Studies with fixed-aspect hydroacoustics and the DIDSON/ADCP were not conducted because of insufficient funding and concern about interference. Nevertheless, the need for multiple evaluation tools likely will arise at USACE projects in future years, because of the advantages of non-intrusive methods to make total population assessments of fine-scale distributions and 
behaviors. This optimization study will be useful for planning future evaluations involving JSATS and other acoustic technologies.

\subsection{Objectives}

The objectives for the acoustic optimization study at JDA during January and February 2008 were as follows:

- Design and test prototypes and provide a total needs list of pipes and trolleys to deploy JSATS hydrophones on the forebay face of the powerhouse and spillway.

- With JSATS tags arrayed in the forebay and detected on the dam-face hydrophones, assess the effect on the JSATS data from turbine unit and spillway flows and operations of a DIDSON, an ADCP, and a fixed-aspect, PAS hydroacoustic system.

- Determine the relationship between fixed-aspect hydroacoustic transmit level and mean percentage of JSATS transmissions decoded.

\subsection{Study Area}

PNNL conducted the optimization study at two turbines (Units 14 and 15) and two spill bays (Bays 16 and 17) at JDA (Figure 1.1). These locations were chosen because an equipment trailer could be located between them to minimize cable runs and provide a central location for the equipment. During the optimization study, total river discharge was about $115 \mathrm{kcfs}$ to $135 \mathrm{kcfs}$. Water temperature (scroll case) was $\sim 5^{\circ} \mathrm{C}$.

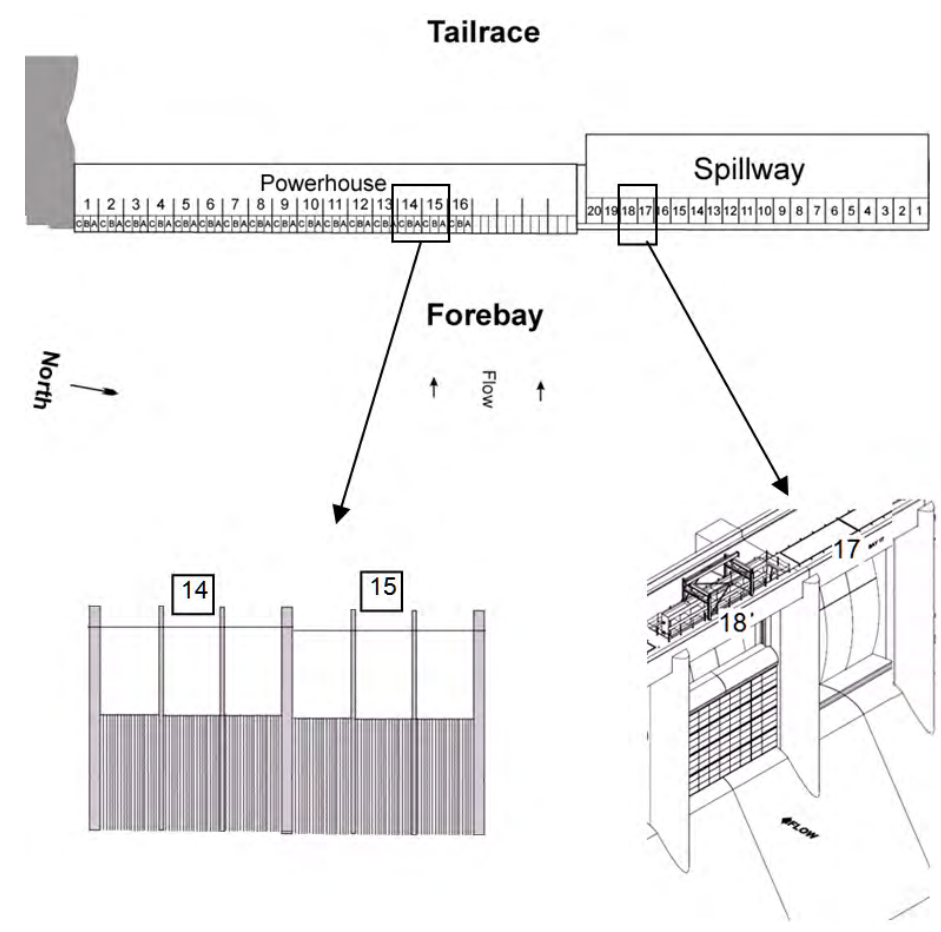

Figure 1.1. Plan Diagram of John Day Dam with Boxes Highlighting Study Sites (top) and Frontal Views of Specific Study Areas (bottom). 


\subsection{Report Contents}

The ensuing sections of this report describe the study methods, results, and conclusions. There are no appendices. The raw data are archived at PNNL offices in North Bonneville, Washington. 


\subsection{Methods}

The following description of methods includes the study overview and preparations, followed by deployment, data collection, and data analysis.

\subsection{Study Overview}

The optimization study was conducted to support the TSW evaluation at JDA in the spring and summer of 2008 and subsequent years, with priority placed on the acoustic telemetry study. Accordingly, we were cognizant of advances from the JSATS research and development effort, and incorporated the latest versions of hardware and software for the cabled-JSATS approach that was available at the time of the study. The optimization study also involved design and installation of pipes and trolleys to deploy hydrophones off pier-noses at the powerhouse and spillway. These installations allowed the USACE to facilitate the deployment needed for the full-scale 2008 TSW evaluation.

At the start of the optimization study, we assessed and prioritized JSATS hydrophone deployment alternatives to identify those with the highest probability of meeting needs for data about fish position and route of passage. The generic hydrophone deployment scheme at a given turbine unit or spill bay called for four hydrophones - two near the surface and two at mid-water-to bracket a given passage route (Figure 2.1). Deployments of other acoustic systems depended on the locations of the acoustic telemetry hydrophones (Figure 2.1). PNNL deployed fixed-aspect hydroacoustic transducers at the turbine units and spill bays equipped with hydrophones (see Section 2.3.1). In addition, we deployed the DIDSON/ADCP at a spill bay (see Section 2.3.2).

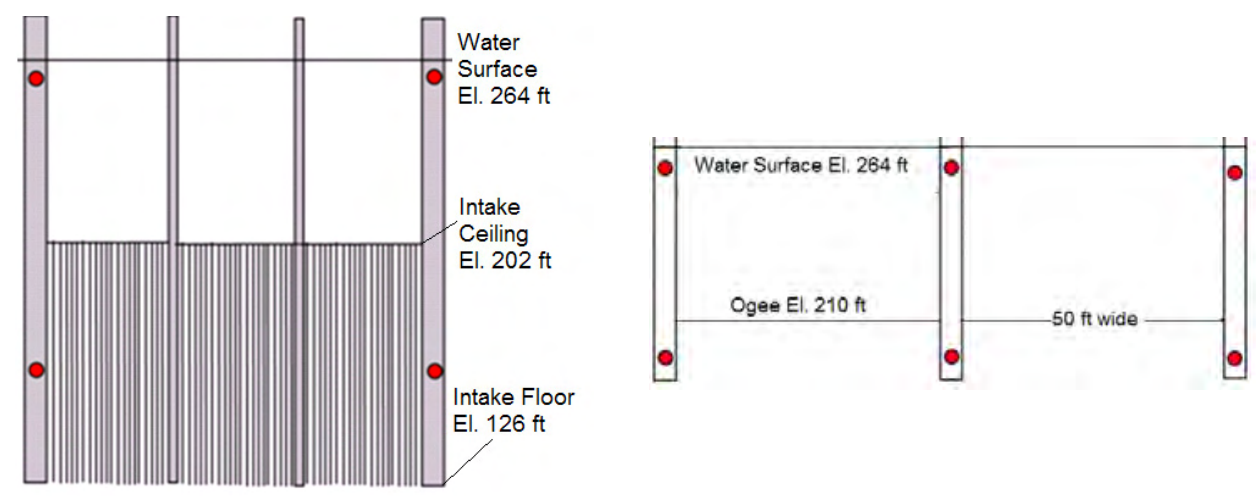

Figure 2.1. Front Views of Generic Hydrophone Locations (red dots) at a Turbine Unit (left) and Spill Bays (right) at John Day Dam.

The general approach was to use the hydrophones to listen for transmissions from JSATS tags deployed in vertical arrays in a series perpendicular to the face of the dam (see Section 2.3.5). PNNL used the JSATS acoustic telemetry equipment and a second system developed by Teknologic LLC (see Section 2.3.3). In addition, we used two versions of the JSATS signal detector (V2.0 and V2.5 and decoder software (TDOA2 and TDOA6.5) (old and newest at the time of this study) and two different types of hydrophone baffling (see Section 2.3.4). The optimization study consisted of a suite of off/on treatments (Table 2.1). The primary response variable was the mean percentage of JSATS tag transmissions decoded (see Section 2.5). 
Table 2.1. General Test Treatments for the Acoustic Optimization Study at John Day Dam, January and February 2008. The boxes indicate test conditions: clear box means off, solid box means on.

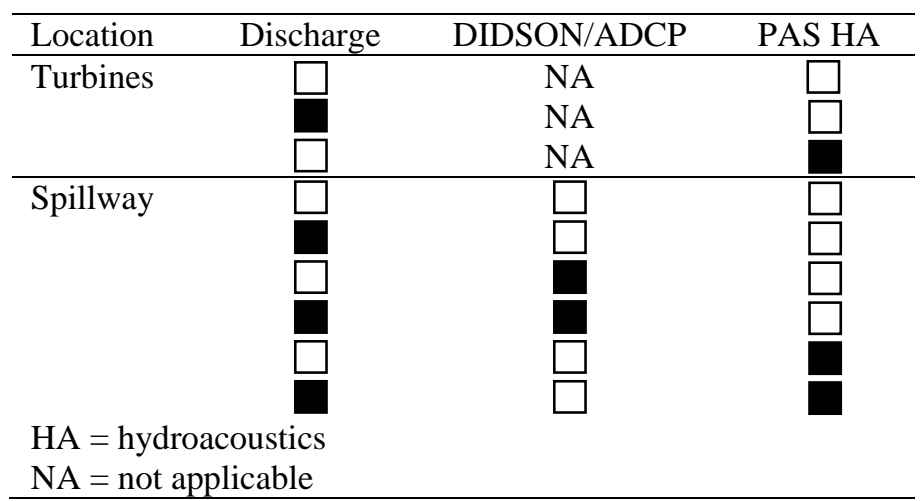

\subsection{Study Preparations}

Preparation for conducting the study started with obtaining the necessary permissions and security access to the dam for all required staff. PNNL conducted a hazards analysis, developed a safety plan, and received a safety briefing from project personnel. Communication avenues were established between PNNL and USACE staff at the project and at Portland District headquarters.

PNNL developed a detailed work plan describing the treatments and a schedule for acquiring data. This plan was reviewed with USACE staff. Key elements of the work plan were the need for pipes and trolleys for the hydrophones, divers for their installation, and preliminary laboratory testing.

\subsubsection{Pipes and Trolleys for Hydrophones}

PNNL evaluated pipe and trolley materials to use to deploy the hydrophones. PNNL selected 4-in. diameter slotted pipe to assemble two 120-ft long sections of pipe for installation on two main piers on either side of Unit 15 at JDA. The list of materials and design drawings were reviewed by USACE structural engineers for feedback and submitted to the Project for installation approval at turbine unit 15 for optimization testing. The design called for the pipe to run from deck level (El. $281 \mathrm{ft}$ ) down to midintake depths (El. $164 \mathrm{ft}$ ) (Figure 2.2). PNNL provided final specifications and cost estimates for the Portland District to procure and install slotted trolley pipe on every main pier between turbines and inspect, repair, and modify pipe at the spillway, as needed. At the conclusion of this preparation step, PNNL gave the USACE a list of pipe and hardware required to outfit the powerhouse and spillway for the 2008 acoustic telemetry study. 


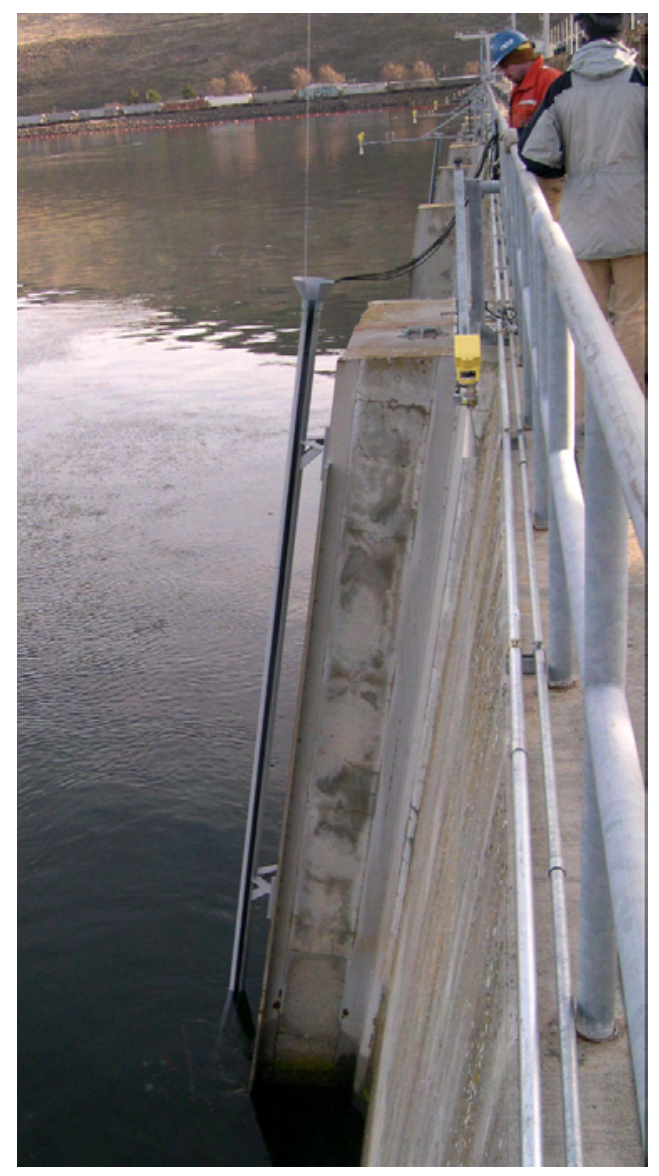

Figure 2.2. Pipe with Funnel for Acoustic Telemetry Trolley and Hydrophone Attached to a Powerhouse Pier-Nose at John Day Dam.

PNNL also designed and fabricated funnels for the top of 8-in.-diameter pipe currently installed at the spillway. These funnels were attached to the tops of three existing pipes at spillway piers 16/17, 17/18, and 18/19 (where numbers reference spill bay and the slash indicates the pier between adjacent bays). The funnels proved very useful for guiding trolleys into pipes, and PNNL recommended purchasing funnels for all pipes that were subsequently installed at the powerhouse and added to existing spillway pipes in spring 2008. For the optimization study, we designed and built prototype trolleys-four trolleys for a turbine and six trolleys for the spillway.

PNNL and Honald Crane installed a 4-in.-wide flange beam on the pier between Spill Bays 19 and 20 on November 16, 2007. Old trolleys from all 8-in.-diameter spillway pipes were also removed in late November 2007. The USACE contracted with a remote operated vehicle (ROV) operator to inspect all attachments of existing 8-in.-diameter pipes to piers at the spillway and inspect the pipes for damage. PNNL designed and contracted the manufacture of hydrophone trolleys designed to slide down and up in slotted pipes at the powerhouse and spillway. Part of the ROV inspection involved running newly designed trolleys up and down existing spillway pipes to assure proper clearance throughout the length of each pipe. During the week of December 17, 2007, PNNL worked with USACE staff at the dam, Honald Crane, and contract divers to install 4-in.-diameter slotted pipe on main piers on each side of turbine unit 15. 


\subsubsection{Dive Plans}

To perform underwater inspections at the spillway and install new prototype pipes at turbine unit 15, PNNL helped the USACE develop dive plans for USACE subcontractor divers. The dive plans also addressed installation of PAS hydroacoustic transducers in Turbine Intakes 14A and 15C.

\subsubsection{Preliminary Tests in the Laboratory}

Before optimization testing at JDA, components for each acoustic system to be deployed at the dam were tested in a tank at PNNL offices in North Bonneville, Washington. PNNL conducted transceiver and cable proximity tests to determine whether electrical noise or crosstalk (electromagnetic interference that passes between adjacent devices or cables) could be induced into telemetry cables from the strong synchronization pulse that hydroacoustic transceivers transmit through cables. PNNL observed no crosstalk, even when cables were laid out along side each other and touching over distances exceeding $200 \mathrm{ft}$. From these tests, PNNL concluded that there would be no limitations for deploying hydroacoustic and acoustic telemetry cables at JDA. At this time, receiver-gain settings were calculated to equalize outputs for a variety of transmit power levels from hydroacoustic transceivers.

\subsection{Deployment}

It was critical to deploy each type of equipment so that sound transmissions from fixed-hydroacoustic transducers, the DIDSON, and the ADCP would not be aimed directly at the JSATS hydrophones. Options for deploying fixed hydroacoustic equipment were identified in a previously successful optimization study in fall 2001 (Ploskey et al. 2002), and flexibility in deployment locations and aiming angles is relatively limited. Turbines typically are sampled by deploying pairs of up-looking transducers inside intakes on the downstream side of trash racks. Spill bays are sampled by deploying down-looking transducers just below minimum pool and as close to the Tainter gate as possible to detect fish that are committed to passing under the gate. Hydroacoustic sampling of fish passing a surface flow outlet usually is done by deploying up-looking or side-looking split beam transducers on the upstream side of the outlet (Johnson et al. 2006). Relevant specifications for the acoustic systems deployed in this study are provided in Table 2.2.

Table 2.2. Relevant Specifications for the Acoustic Systems

\begin{tabular}{ccc}
\hline System & Sound Frequency $(\mathrm{kHz})$ & Ping Rate $(\mathrm{pps})$ \\
\hline JSATS Tag & 416 & 0.2 \\
PAS Hydroacoustics & 420 & 25 \\
DIDSON & 1000 & 7 \\
ADCP & 600 & \\
\hline
\end{tabular}

\subsubsection{PAS Hydroacoustic Transducer Locations}

PNNL deployed one up-looking PAS split-beam hydroacoustic transducer inside turbine Intake 14A and another in Intake 15C during the week of December 17, 2007. Each transducer was aimed above the intake screen to sample guided fish (Figure 2.3) because this deployment generated the maximum sound volume reverberation and would provide a worst-case test. We did not deploy transducers for sampling 
on unguided fish, because that aiming angle reflects significantly less sound back toward the forebay than sound transmitted into areas upstream of the fish screen in the turbine intake. Hydroacoustic-on treatments at the turbine consisted of alternating sound transmissions at 25 pings per second for 1 minute each from the transducers in Intakes 14A and 15C. Turbine-on treatments consisted of running Units 14 and 15 at an average loading that might be expected during the fish-migration season ( 125 MW per unit).

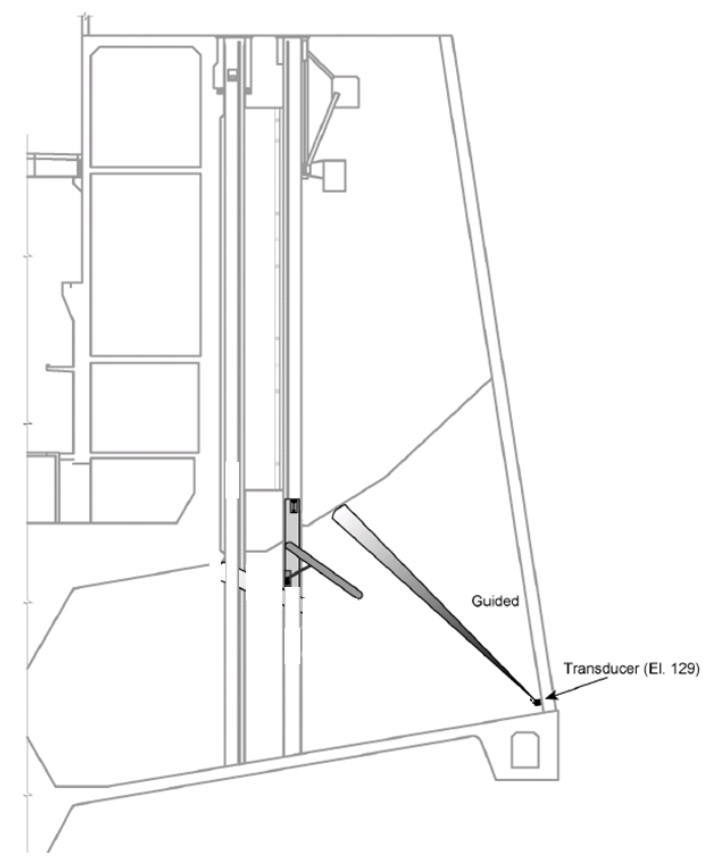

Figure 2.3. Turbine Cross Section Showing a Single Hydroacoustic Beam for a Transducer Sampling Guided Fish Passing Above a Submersible Traveling Screen. Typically, one intake of three per turbine is randomly selected for sampling and an upper beam is aimed to sample guided fish passing above the submerged traveling screen (as shown and deployed in this study), and a lower beam samples unguided fish passing below the tip of the screen (not shown nor deployed in this study).

PNNL also deployed two down-looking single beam PAS transducers at Spill Bay 17 during the week of November 2, 2007 (Figure 2.4), and three up-looking PAS split-beam transducers were installed on the ogee upstream of Spill Bay 18 during the week of December 17, 2007 (Figure 2.5). During testing in January and February 2008, hydroacoustic-on treatments at the spillway consisted of sound transmissions at 25 pings per second for 1 minute alternating continuously among the three split-beam transducers and simultaneous transmission at 25 pings per second from one of the two single-beam transducers, which also alternated sampling at 1-minute intervals. For spillway tests, we also had treatments in which all hydroacoustic transducers operated at transmission levels ranging from $-6 \mathrm{~dB}$ (full power) to $-12 \mathrm{~dB}$ (minimum power) in 1-dB increments. Spill-on treatments consisted of $3 \mathrm{kcfs}$ spill through Spill Bay 18 and 19. 


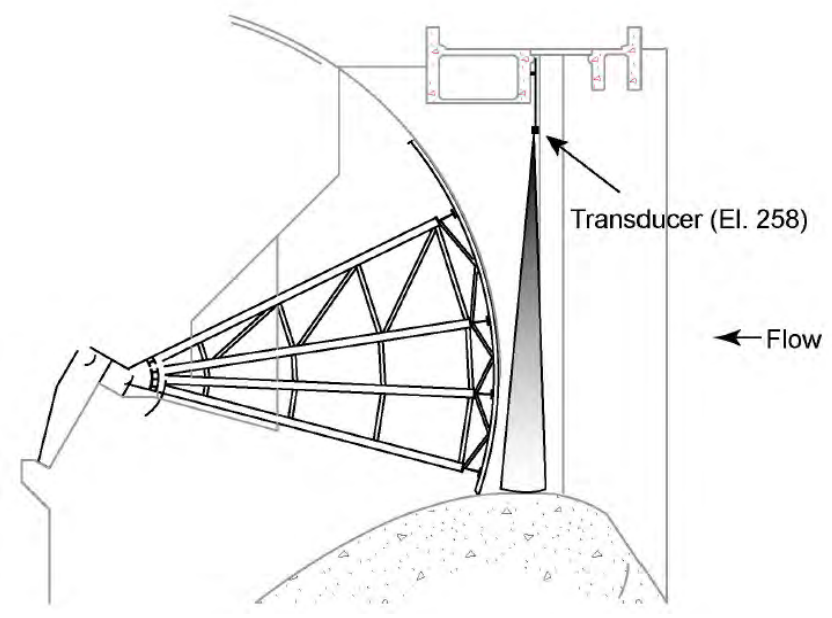

Figure 2.4. Cross-Sectional View of a Spill Bay Showing a Hydroacoustic Beam Deployed Just Below the Water's Surface and Aimed Slightly Downstream Off of Vertical. Typically, every operational spill bay is sampled in a fish-passage efficiency study.

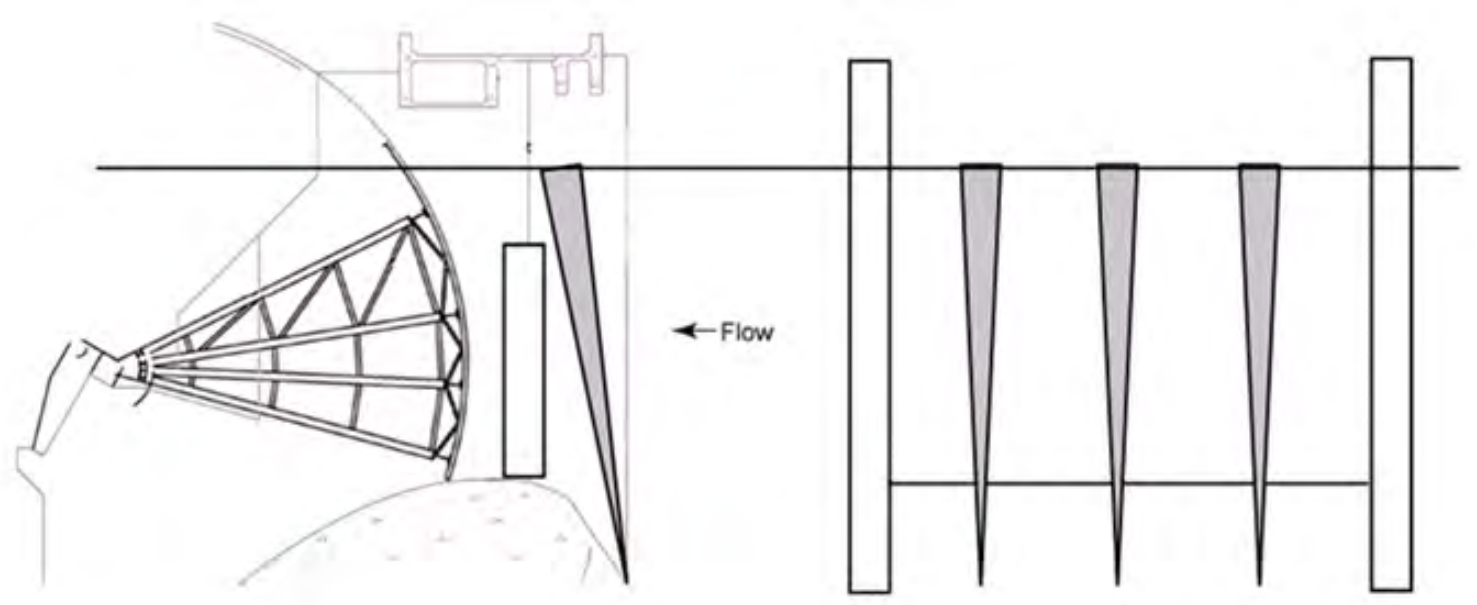

Figure 2.5. Cross-Sectional View of a Spill Bay with a Top Spillway Weir (TSW) and the Proposed Aiming Angle for Three Split-Beam Transducers (left) and a Front View of the Same TSW Bay Showing the Split Beams (right). Note that stop logs were not deployed in Spill Bay 18 to simulate a TSW, as indicated in the side view.

\subsubsection{DIDSON/ADCP Location}

Previous deployments of the DIDSON and ADCP have been successful (Johnson et al. 2008), although options are limited by the relatively short sampling range, which dictates that the instruments be deployed near the outlet to be sampled. Those instruments usually are mounted together on a trolley lowered down the inside of a pier adjacent to an outlet (Figure 2.6). In practice, the DIDSON and ADCP are rotated together to sample fish approaching an outlet (Figure 2.7). 

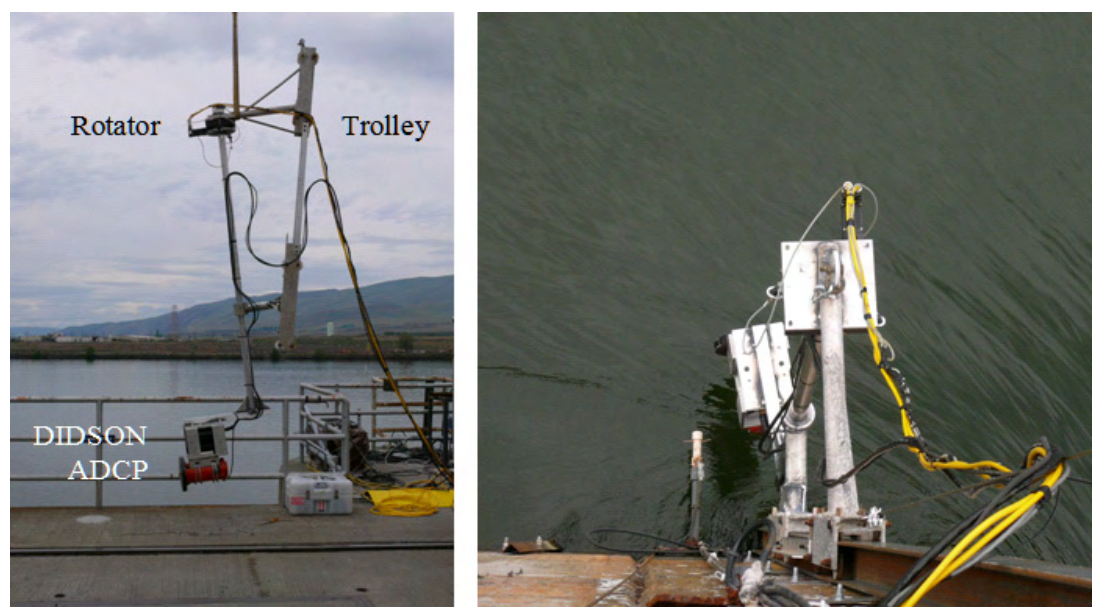

Figure 2.6. Photographs of a Trolley/Rotator Package for Deploying the DIDSON and ADCP (left) and the Loaded Trolley Being Lowered Down a 4-by-4-in. Box Beam at The Dalles Dam (right).

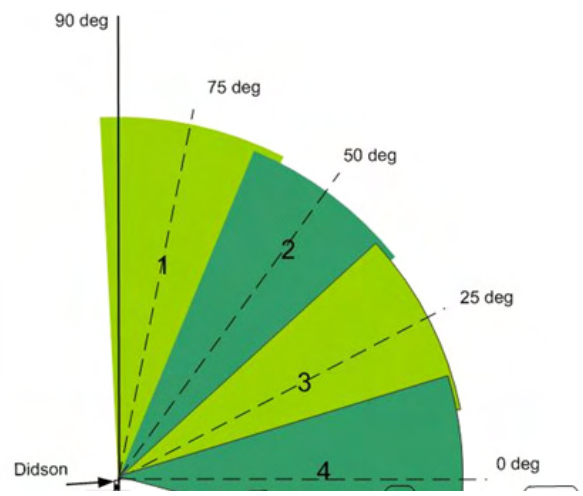

Figure 2.7. Plan View of a Generic DIDSON/ADCP Deployment Showing Sampling Zones Covered by Rotating the Aiming Angle of the Instruments

\subsubsection{Electronics and Acoustic Telemetry Hydrophones}

PNNL mobilized a field crew and equipment to deploy hydroacoustic and acoustic telemetry equipment at one turbine and one spill bay, and hydroacoustic, acoustic telemetry, and DIDSON/ADCP equipment at an adjacent simulated "TSW" bay. The positions of the equipment were surveyed using a real-time kinematic system and total station. Two global positioning system (GPS) receivers were used to provide accurate time data for all data acquisition systems.

On January 10 and 11, 2008, PNNL set up hydroacoustic and acoustic computers and data-acquisition equipment. Acoustic telemetry hydrophones mounted on 4-in.-diameter trolleys were deployed at Turbine Units 14 and 15 on January 14, and testing occurred on January 15 and 16. Main piers on either side of turbine unit 15 each received one deep trolley $(101 \mathrm{ft}$ ) and one shallow trolley $(5 \mathrm{ft}$ deep; Figure 2.8). Each trolley supported one old-style Sonic Concepts hydrophone (a 22-degree beam 360 degrees around the tip) and one new hydrophone (one 180-by-180-degree hydrophone on each deep trolley and one 90-by-180-degree hydrophone on each shallow trolley). Baffling consisted of a 3-ft-wide and 2-ft-high backboard of plywood covered with rubber and rubber paint over supporting bolts. The shallow trolley on the Pier 14/15 also supported a JSATS mobile hydrophone. 


\section{Side View $\quad$ Front View}

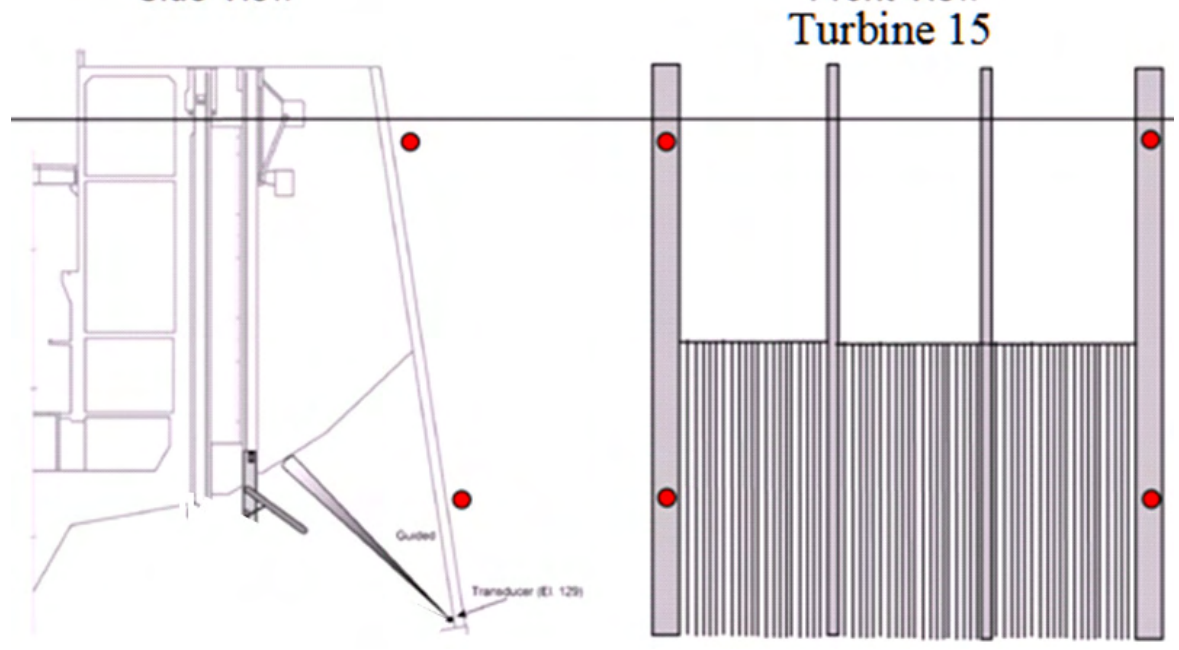

Figure 2.8. Diagram Illustrating the Location of JSATS Hydrophones (Red Dots) on the Main Piers in Side View (Left) and in Frontal View (Right). Horizontal separation of nodes at the same elevation was about $90 \mathrm{ft}$. Vertical separation of nodes on the same pier was about $96 \mathrm{ft}$.

Acoustic telemetry hydrophones were pulled from turbine piers and moved to the spillway for testing on January 17, 2008. At the spillway, six trolleys were deployed (Figure 2.9), each of which had 3-ftwide, 2-ft-deep backboard baffles, as described in the previous paragraph. Deep trolleys on Piers 17/18 and 18/19 each had three hydrophones, two typical (same as used on autonomous receivers) Sonic Concepts (SC) hydrophones (22-degree reception 360 degrees around the tip), and one new 180-by-180degree hydrophone. The shallow trolleys each had two typical Sonic Concepts hydrophones and one new 90-by-180-degree hydrophone. The shallow trolley on Pier 17/18 also supported a JSATS mobile hydrophone that was cabled to a JSATS mobile processing unit similar to the board set in autonomous nodes. That hydrophone also had a nominal 22-degree receiving beam that emanated 360 degrees around the hydrophone tip. One of the typical SC hydrophones on each of the four trolleys on Piers 17/18 and 18/19 was cabled to PAS quad channel amplifiers and computers running PNNL detection software and the other typical SC hydrophone on each trolley was cabled to a four-channel processing system operated by Teknologic LLC. The 90-by-180- and 180-by-180-degree hydrophones were cabled to PAS quad channel amplifiers and computers running PNNL detection software. Trolleys on spillway Pier 16/17 each supported one typical SC hydrophone.

\subsubsection{Hydrophone Baffles}

Two types of baffles were deployed for the hydrophones; first plywood covered with a rubber material, then anechoic (Figure 2.10). The intent of the plywood baffle was to shield the hydrophone(s) from acoustic energy emanating from sources behind the baffle, e.g., split-beam hydroacoustics. The plywood baffle did not work well; the anechoic baffle was used instead. 


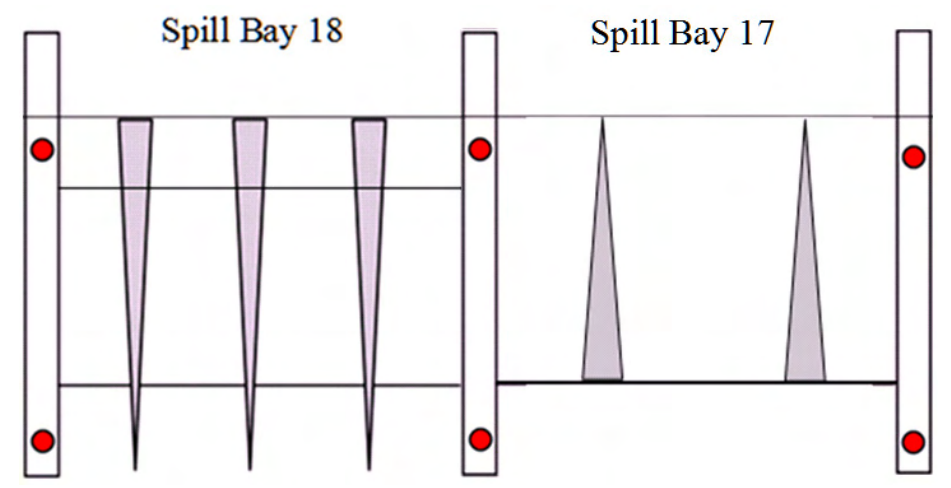

Figure 2.9. Front View Illustrating the Approximate Location of JSATS Hydrophones (red dots) on Main Spillway Piers 16/17, 17/18, and 18/19. Spacing between hydrophones was purposefully asymmetrical in the vertical dimension. Horizontal separation of hydrophones was about $60 \mathrm{ft}$ and vertical separation ranged from 24 to $31 \mathrm{ft}$. Shallow and deep trolleys were deployed at depths of 7.8 and $31.8 \mathrm{ft}$ (Pier 18/19), 3.5 and $34.6 \mathrm{ft}(17 / 18)$, and 7.9 and $37.8 \mathrm{ft}$ (Pier 16/17).
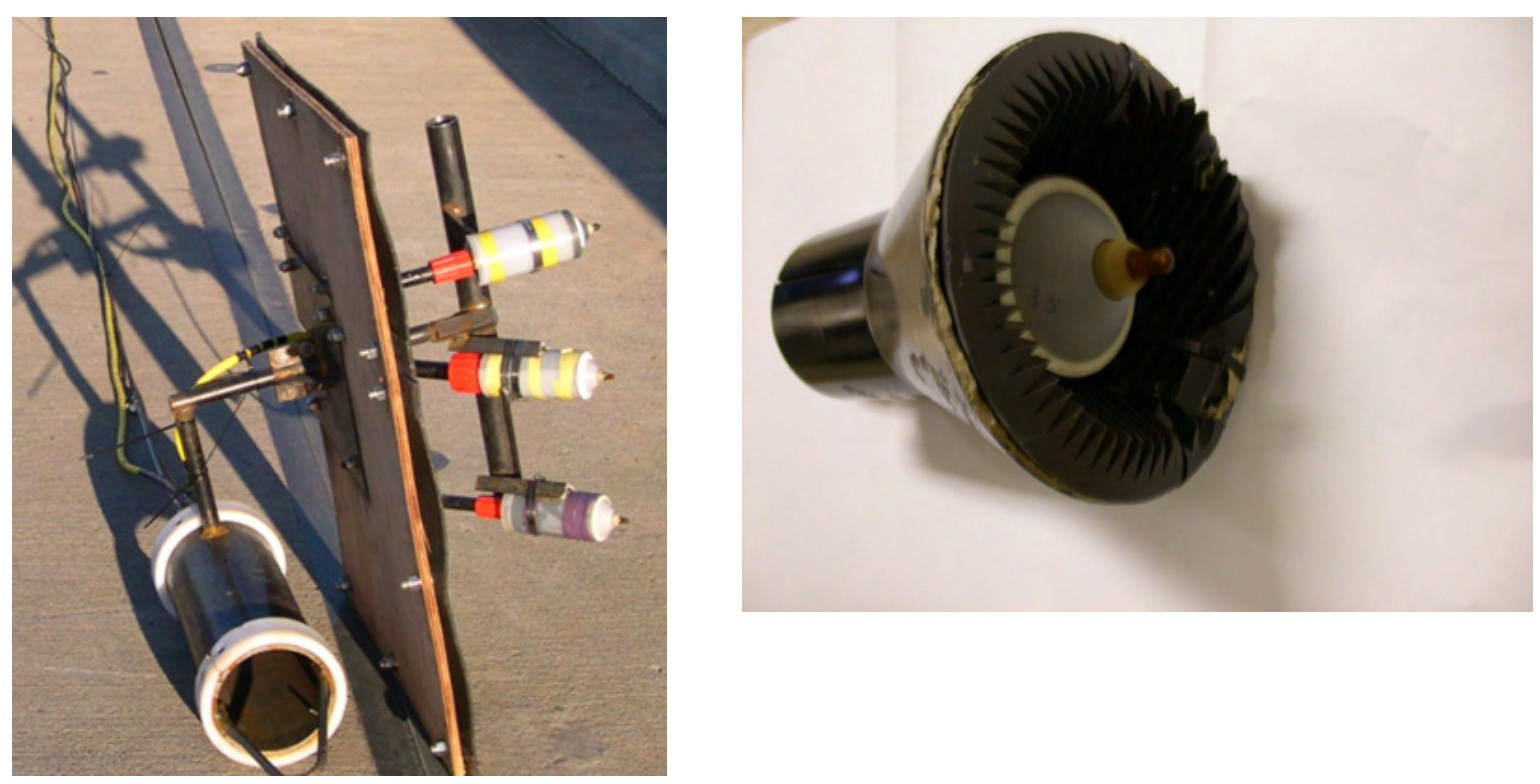

Figure 2.10. Photographs of the Plywood Baffle (left) and the Anechoic Baffle (right)

\subsubsection{Acoustic Telemetry Tag Line}

The primary method for evaluating interference to the JSATS data was to deploy a complex acoustic tag line in the forebay emanating upstream from near the center of hydrophone locations at the powerhouse and spillway. JSATS tags were deployed in vertical arrays in series in the tag line perpendicular to the face of the dam (Figure 2.11and Figure 2.12). 


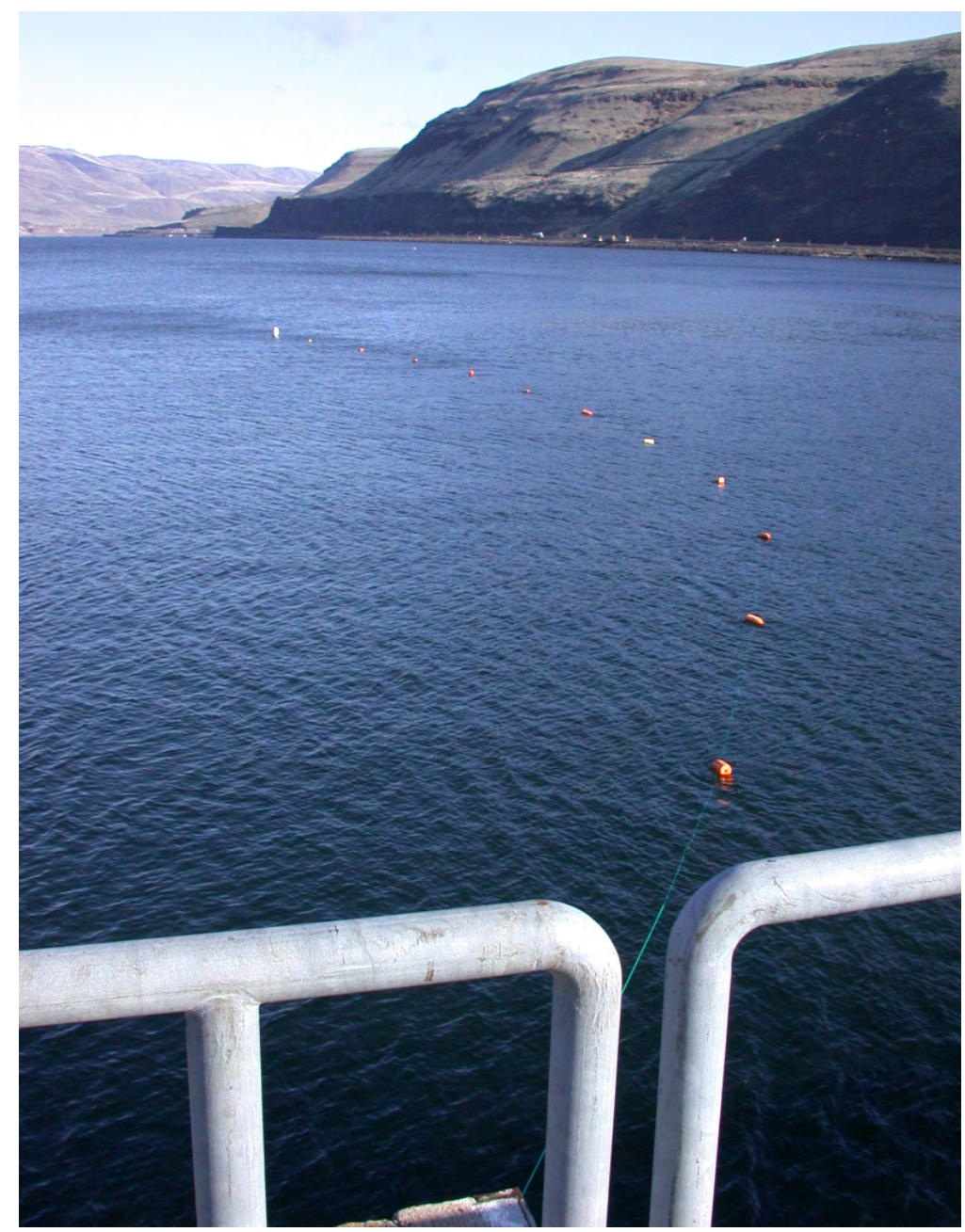

Figure 2.11. Tag Line with a Series of Vertical Arrays of JSATS Transmitters

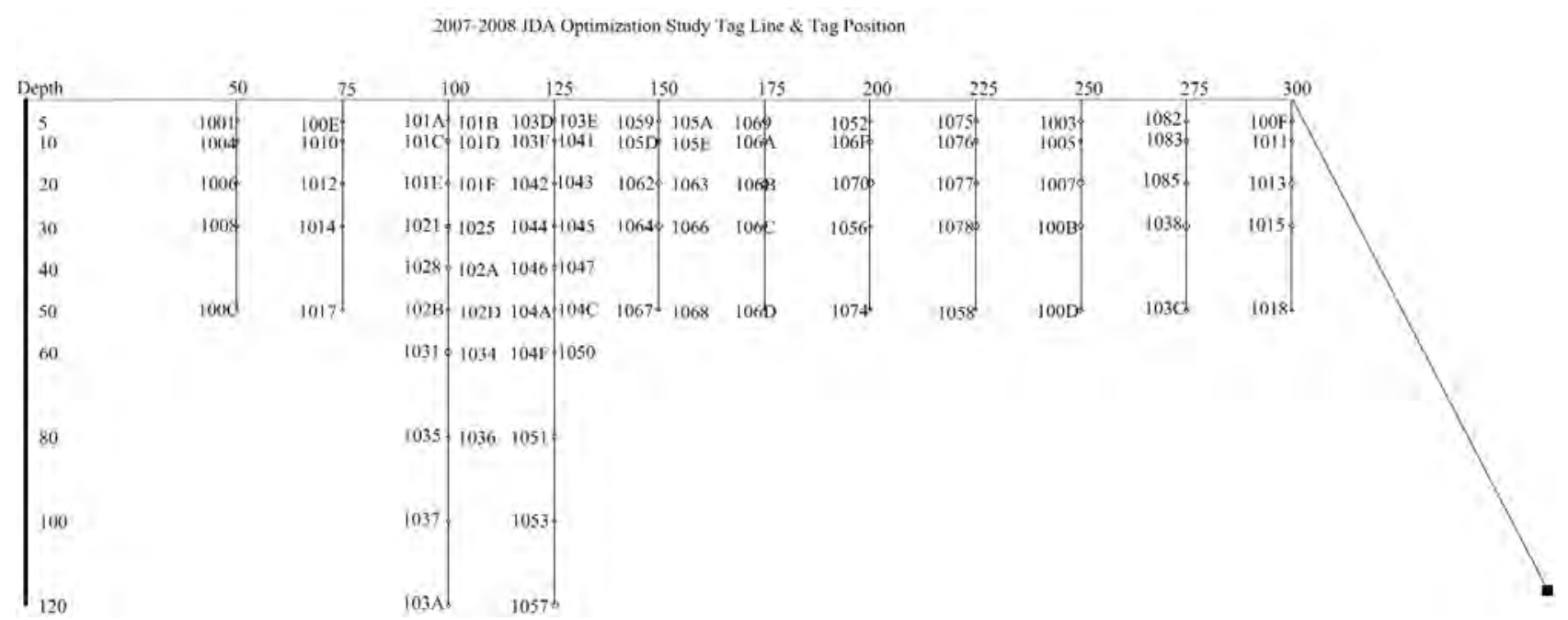

Figure 2.12. Tag Line Deployed Upstream of Pier 15/16 at the Powerhouse and Upstream of Spillway Pier 17/18. Each drop line had a float at the top and a 5-lb weight at the bottom. 
The tags deployed for testing during the week of January 13, 2008, did not have equal detectability because of differences in range from hydrophones and especially the narrow nominal beam angle of most typical SC hydrophones deployed on the dam face. Teknologic LLC determined that the nominal beam angle of old style hydrophones was not 45 degrees as assumed at the start of the study but only about 22 degrees at $6 \mathrm{~dB}$ down from the target strength of an on-axis target. We suspect that the 22-degree beam angle of these typical SC hydrophones works well when the hydrophones are moving back and forth like those on JSATS autonomous nodes anchored in flow, but they are much less effective when deployed in a fixed position as in this study. Given the deployment angles of the typical SC hydrophones and the mobile hydrophone, the center of the 22-degree beam from deep deployments intersected the water's surface within $50 \mathrm{ft}$ of the dam face. The center of the 22-degree beam would have hit the bottom of the forebay within about $75 \mathrm{ft}$ of the dam face. Even given detection of multipath signals (those bouncing off of the bottom or surface before detection), only tags relatively near the dam face and at certain depths would have been consistently detectable by the typical SC hydrophones. The wideaperture, new hydrophones that were 90 by 180 degrees or 180 by 180 degrees had a distinct advantage over the typical SC, narrow-beam hydrophones.

\subsection{Data Collection}

Data collection involved the use of drogues to test 2-D tracking algorithms (part of another study) and additional testing of the effects of hydroacoustic transmission levels, prior to demobilization of study equipment.

\subsubsection{Drogue Drags}

Drogues were built that consisted of a 30-ft long vertical line with an acoustic tag attached at 5-ft-depth intervals below a float with a GPS antenna. Two drogue lines were dragged through the hydrophone arrays upstream of the Turbine Units 14 and 15 and Spill Bays 16 to 19. These data were valuable for development of two-dimensional (2-D) tracking algorithms (not part of the optimization study) for the 2008 TSW evaluation at JDA, but were not useful for evaluating the effects of hydroacoustic sampling, DIDSON/ADCP sampling, turbine operation, nor spill, because the mean percentage of JSATS transmissions decoded could not be obtained reliably and consistently. We mention the drogue drags here because they will be an important component of the tracking development effort to be reported elsewhere by other PNNL researchers.

\subsubsection{Testing Effects of Hydroacoustic Transmission Level}

Upon completion of testing at the turbine and spillway during the week of January 13, 2008, processing of the data generated additional questions that needed to be evaluated. Preliminary results clearly indicated that running hydroacoustics at high power (-6 dB) had a negative effect on JSATS decoding performance. PNNL also suspected that the backboard-style baffling used during the first week may have allowed an excessive amount of acoustic energy to reach the telemetry hydrophones. In response, a new, anechoic material was used to baffle the hydrophones. Subsequent testing, however, revealed that decoding performance was poor with both types of baffling when hydroacoustics was transmitting at high power $(-6 \mathrm{~dB})$. 
Additional testing was conducted at John Day spillway during the week of February 3, 2008 using individual baffles on 90-by-180-degree and 180-by-180-degree hydrophones cabled to quad channel amplifiers and computers running the latest detection software. During these tests, hydroacoustic transducers were operated at a range of transmission levels -- from -6 to $-12 \mathrm{~dB}$ in $1 \mathrm{~dB}$ increments -- to quantify the effects of hydroacoustic transmission level on acoustic telemetry decoding performance. For these tests, a single vertical line of tags was located $100 \mathrm{ft}$ away from the upstream face of the spillway.

\subsubsection{Post-Study Demobilization}

Demobilization involved removing, cleaning, and storing the equipment. Divers were needed to extract the two in-turbine transducers and the three up-looking spillway transducers. The equipment was not removed immediately after the week of field testing, allowing for a second round of testing during the last week of January and first week of February to quantify the effect of varying hydroacoustic transmit levels on acoustic telemetry performance. All equipment was demobilized by late February 2008.

\subsection{Data Analysis}

The basic data set for analysis consisted of all decoded transmissions from JSATS tags arrayed in the forebay and detected on hydrophones on the face of the dam. This data set was organized by topic (e.g., PAS tests) and test treatment (e.g., spillway OPEN, DIDSON/ADCP OFF and PAS hydroacoustics ON) (Table 2.1). Data from the hydrophones at the spillway and turbine locations were analyzed separately. For a given topic, analysis started with the "control" test condition and determination of which JSATS tags could even be heard under ambient conditions. All tags could not necessarily be heard because of range, orientation, hydrophone receiving characteristics, etc. It was important to include only tags that could be heard to avoid biasing the data set being analyzed. By definition, a tag could be "heard" if $70 \%$ or more of its transmissions were successfully decoded from a given hydrophone.

The next step in data analysis for a particular test treatment was to count the number of decoded transmissions for each hydrophone from the tags identified previously, but at this point under the conditions of the test treatment. Because the transmission rate of the JSATS tags was known (1 per $5 \mathrm{sec}$ ), the total number of individual transmissions for a given tag during the test period could be calculated. Multiple test periods (typically 5-10 min long) were undertaken.

The final step was to calculate the mean percentage of JSATS transmissions decoded for each tag and hydrophone combination separately for a given test treatment. Mean percentage decoded (MPD) was the primary response variable in the optimization study. For a given tag, hydrophone, and test treatment, the equation for MPD was:

$$
\mathrm{MPD}=\frac{\left(\frac{\text { number JSATS tag transmissions decoded }}{\text { total number actual JSATS tag transmissions }}\right) \times 100}{\mathrm{n}}
$$

where, $\mathrm{n}$ is the number of test periods for a particular treatment.

The number of transmissions decoded could exceed the total number of original transmissions, resulting in MPDs greater than $100 \%$, because of multipath. Multipath is the propagation of underwater 
sound energy from the source transmitter to the receiving hydrophone via paths other than the direct path. PNNL included multipath signals in the data analyzed for the optimization study because multipath does not affect the comparison of MPD between control and treatment conditions. Furthermore, including multipath signals maximized the amount of data available for analysis.

Typically, results were displayed in scatterplots of MPD by approximate range (distance) between a given tag and hydrophone. Based on knowledge of the location of each component, range was approximated as the hypotenuse of the triangle for a tag at some horizontal distance from the hydrophone and vertical distance from that horizontal plane.

Data analysis also included box-whisker plots of means, medians, and frequency quartiles to summarize data for various treatments. Linear regressions of MPD on PAS hydroacoustic system transmit level were performed to reveal relationships between these variables. 


\subsection{Results}

The study results are organized by the type of data collection equipment used.

\subsection{Teknologic LLC Equipment}

Data collection with the Teknologic LLC equipment indicated no difference in mean percentage of decoded JSATS transmissions when spill was off versus when spill bays were opened; MPD was approximately 100\% (Figure 3.1a vs. 3.1b). There also was no difference when the DIDSON/ADCP were off and when they were on (Figure 3.1a vs. 3.1c). However, a noticeable difference in MPD was observed when the PAS hydroacoustic system was off compared to when it was on at transmitter power of approximately $-6 \mathrm{~dB}$; MPD dropped from $100 \%$ to $0-50 \%$ (Figure 3.1a vs. 3.1d). The large reduction in MPD shown in Figure 3.1d was caused by the PAS hydroacoustic system even though there was also spill because there was no apparent effect from spill alone (Figure 3.1b).
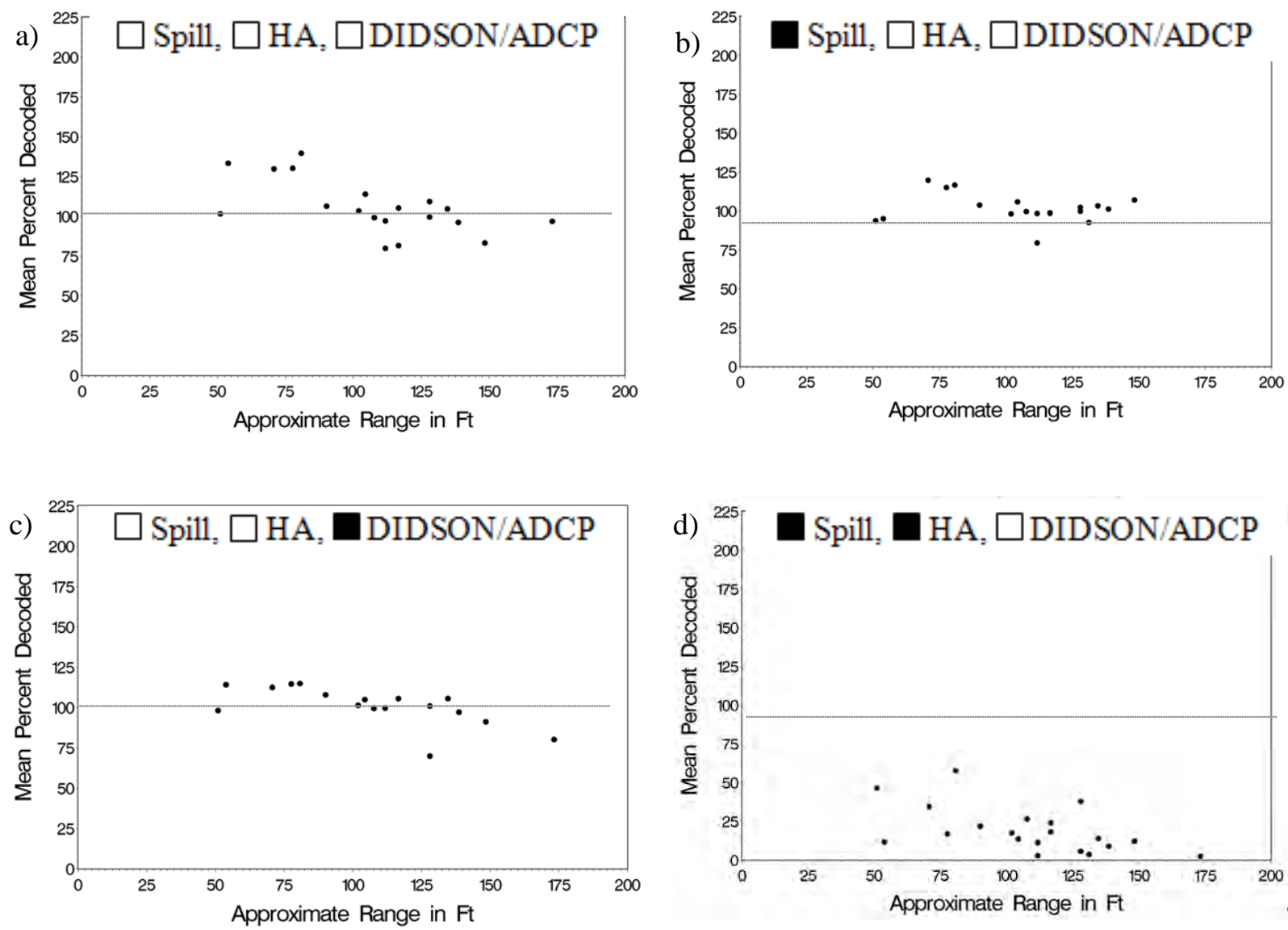

Figure 3.1. Mean Percentage Decoded by Range for Individual JSATS Transmitters Arrayed in the Spillway Forebay of John Day Dam, January and February 2008 - Teknologic LLC Equipment. In this and the figures that follow, the legend indicates study conditions: clear box means OFF, solid box means ON. The reference lines are at MPD $=100 \%$. 
The detector and decoder provided by Teknologic LLC had a MPD that exceeded 100\% for hydroacoustic-off treatments, but the average for hydroacoustic-on treatments (-6 dB hydroacoustic transmit level) was only 19.6\% (Figure 3.2). Similar data reported below were collected with Sonic Concepts and JSATS equipment.

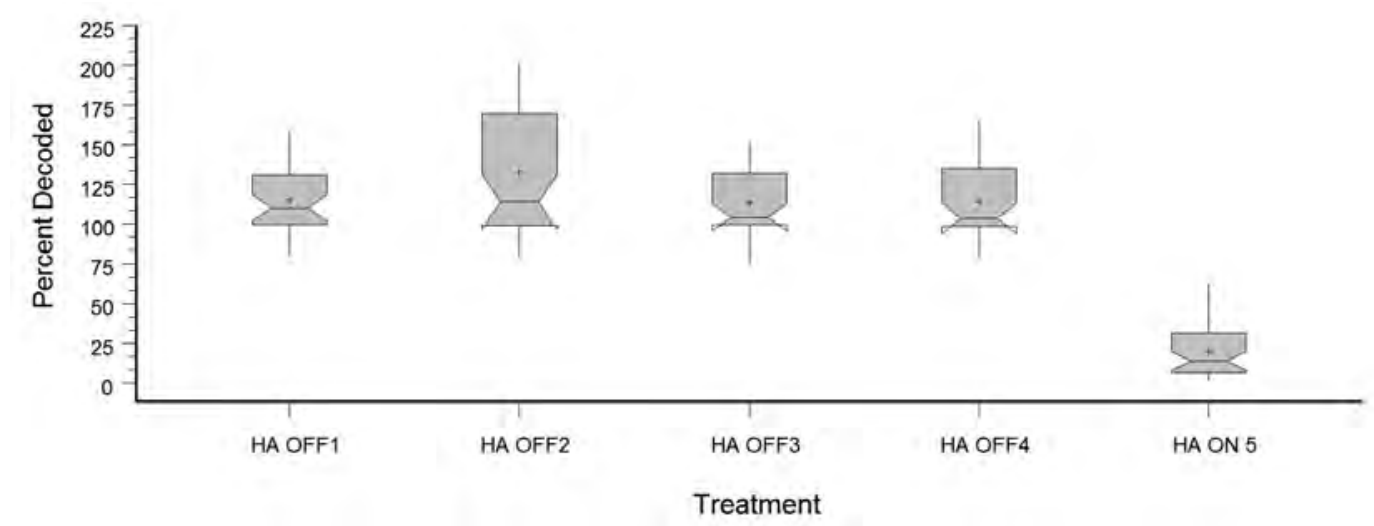

Figure 3.2. Summary Data from Teknologic LLC Detector and Decoder. The "HAOFF" treatments are for various tests when the PAS hydroacoustic system was off.

\subsection{Sonic Concepts and JSATS Equipment}

Results related to the Sonic Concepts and JSATS equipment include the MPD associated with the use of detectors and hydrophones and the operation of turbines, spill bays, a DIDSON/ADCP, a PAS hydroacoustic system, and the transmission levels of the PAS hydroacoustic systems, as described in the following sections.

\subsubsection{Detectors and Hydrophones}

The MPD by range was similar between the old and new detector cards for both the 180-degree hydrophones (Figures 3.3a vs. 3.3c) and the 22-degree hydrophones (Figures 3.3b vs. 3.3d).

\subsubsection{Turbine Operation}

PNNL observed no difference in mean percentage decoded when Turbine Units 14 and 15 were OFF compared to when they were ON (Figure 3.4a vs. 3.4b). The MPD ranged between $70 \%$ and $100 \%$ for both conditions. 

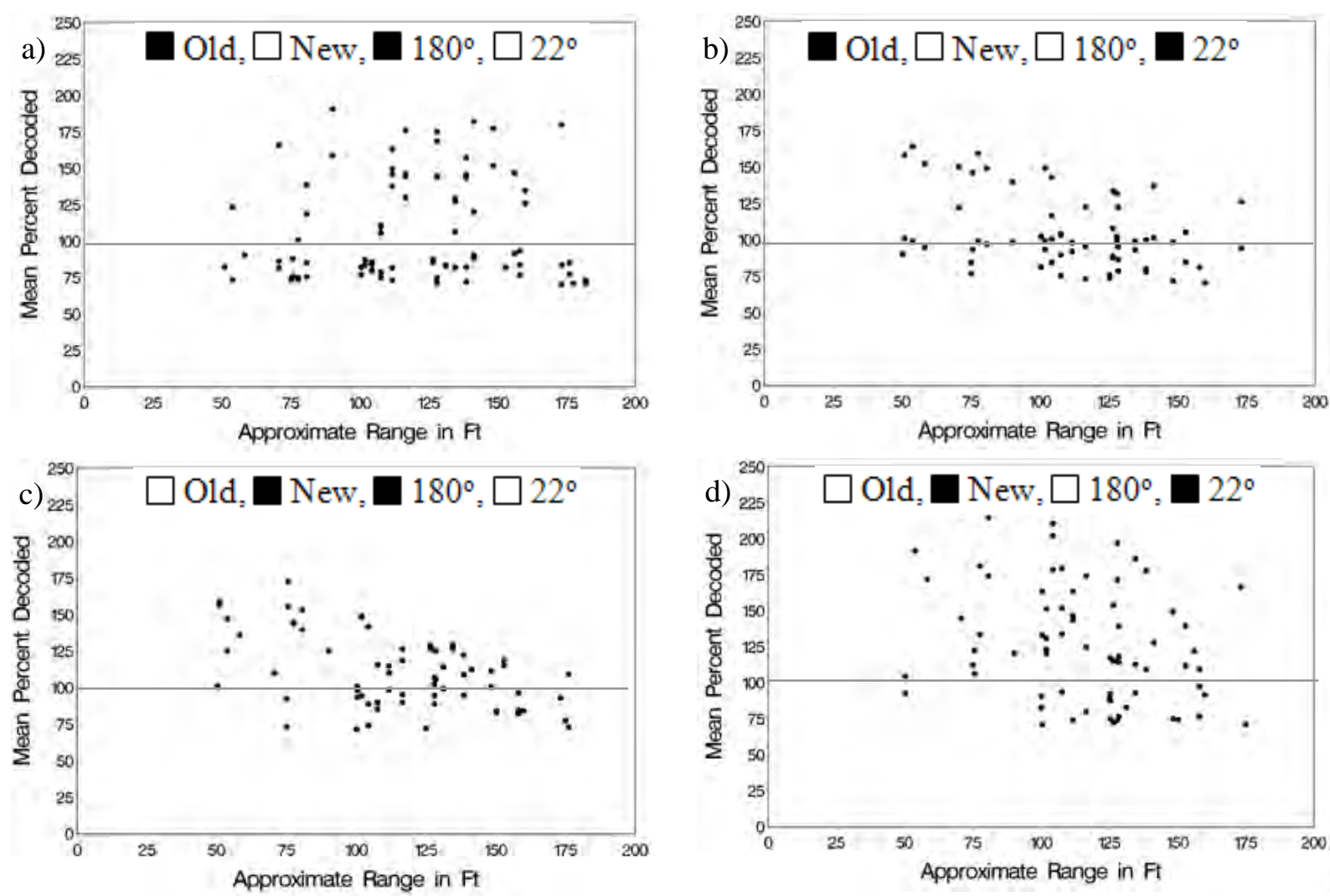

Figure 3.3. Mean Percentage Detected by Range for the Four Combinations of Old and New Detectors and 180- and 22-Degree Sonic Concepts Hydrophones. Data are from the JDA spillway during January and February 2008. 

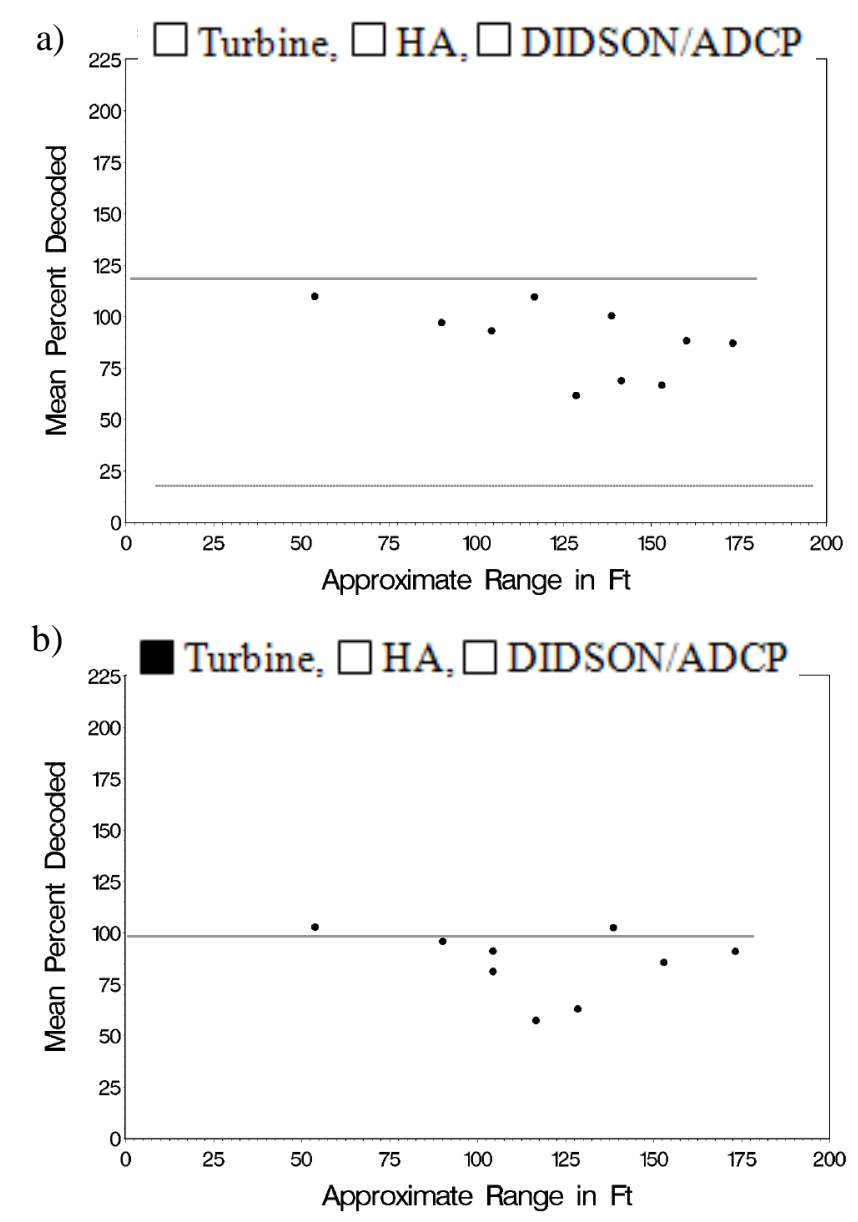

Figure 3.4. Turbine Operation Effects on Mean Percentage Decoded by Range for Individual JSATS Transmitters Arrayed in the Turbine 14/15 Forebay of John Day Dam, January and February 2008 - JSATS “Mobile” Hydrophone, Old Detector, Plywood Baffle. 


\subsubsection{Spillway Operation}

PNNL did not find a difference in MPD when the spillway was closed and when it was open; this was true for both the mobile (Figure 3.1a and 3.1b) and 180-degree hydrophones (Figure 3.5c and 3.5d).
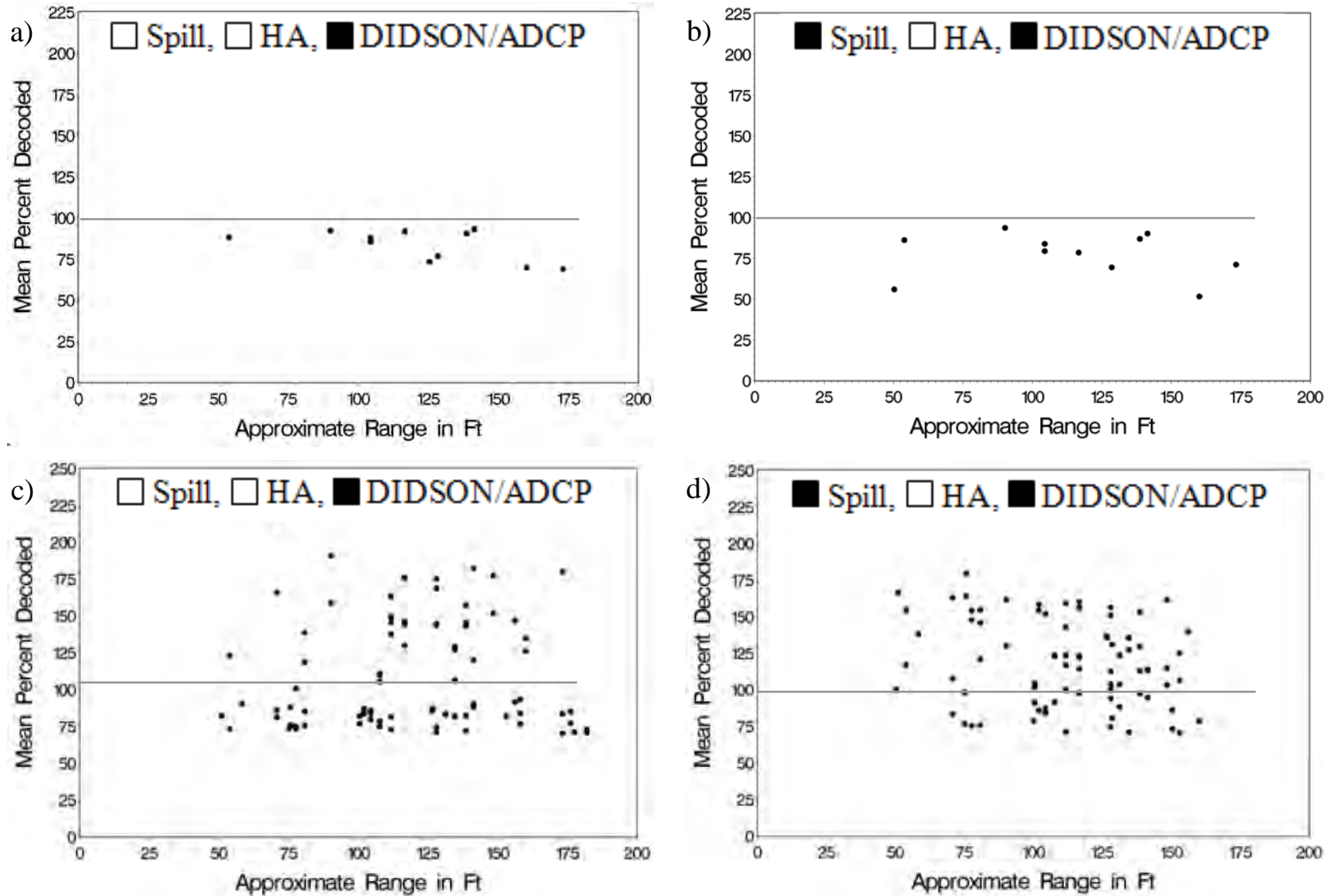

Figure 3.5. Spillway Operation Effects on Mean Percentage Decoded - Old Detector, Plywood Baffle. (a) and (b) JSATS “Mobile” Hydrophone; (c) and (d) 180-degree hydrophone.

\subsubsection{DIDSON/ADCP Operation}

There was no difference in MPD using the JSATS “mobile" hydrophone when the DIDSON/ADCP were off (Figure 3.6a) and when they were on (Figure 3.6b). A similar pattern was observed for the directional hydrophone (Figure 3.6c vs. 3.6d). MPD was $70 \%$ to $100 \%$ or above under both conditions (Figure 3.6a-3.6d). 

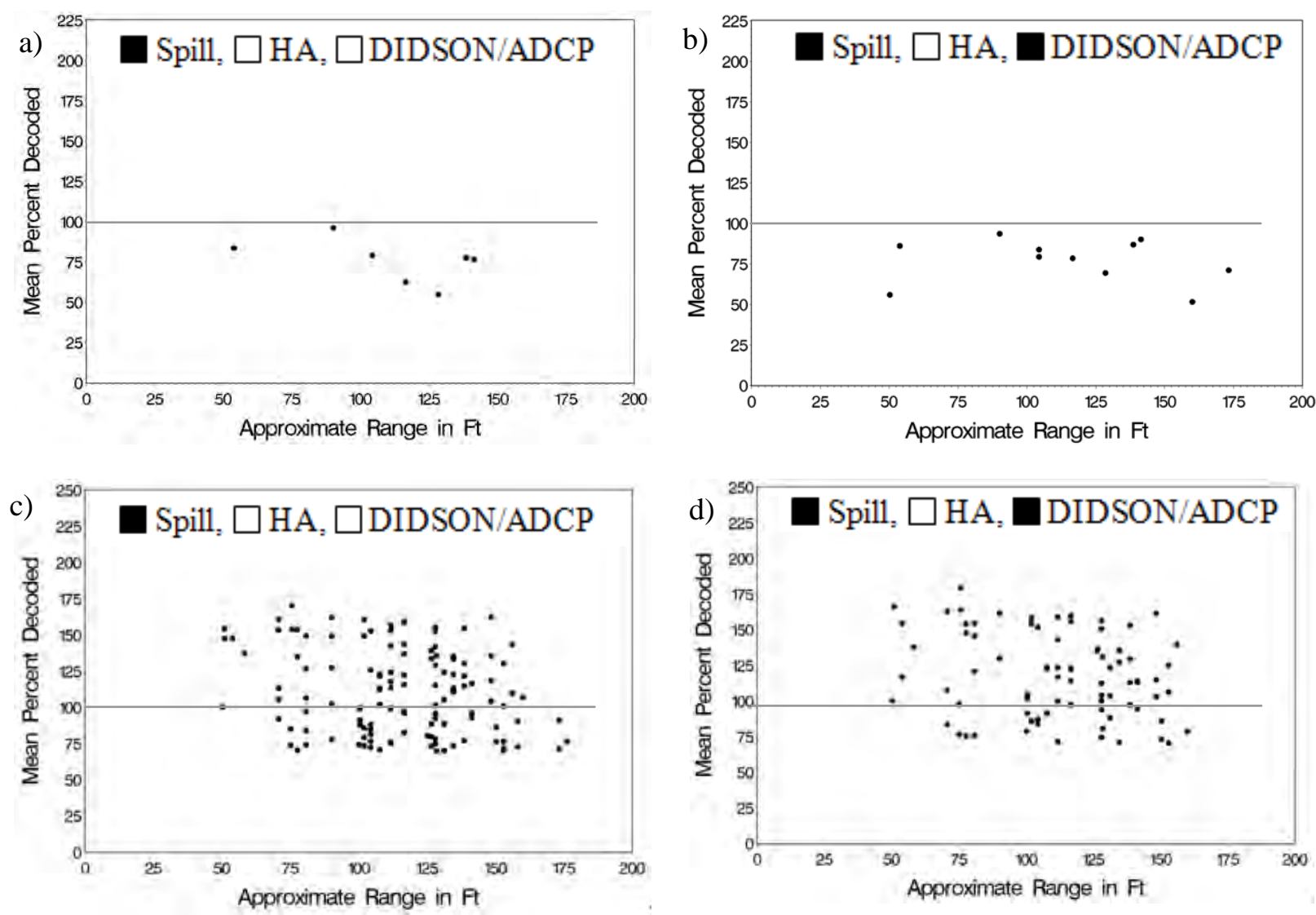

Figure 3.6. DIDSON/ADCP Operation Effects on Mean Percentage Decoded by Range for Individual JSATS Transmitters Arrayed in the Spillway Forebay of John Day Dam, January and February 2008 - Old Detector, Plywood Baffle. (a) and (b) JSATS “Mobile” Hydrophone, (c) and (d) 180-degree hydrophone.

\subsubsection{PAS Hydroacoustic System Operation}

The operation of the PAS hydroacoustic system negatively affected the detection of JSATS transmissions. When the hydroacoustic system was off, mean percentage decoded was much higher than when it was on at the turbines (Figure 3.7a vs. 3.7b), at the spillway with the 180-degree hydrophone (Figure 3.7c vs. 3.7d), and at the spillway with the 22-degree hydrophone (Figure 3.7e vs. 3.7f). 

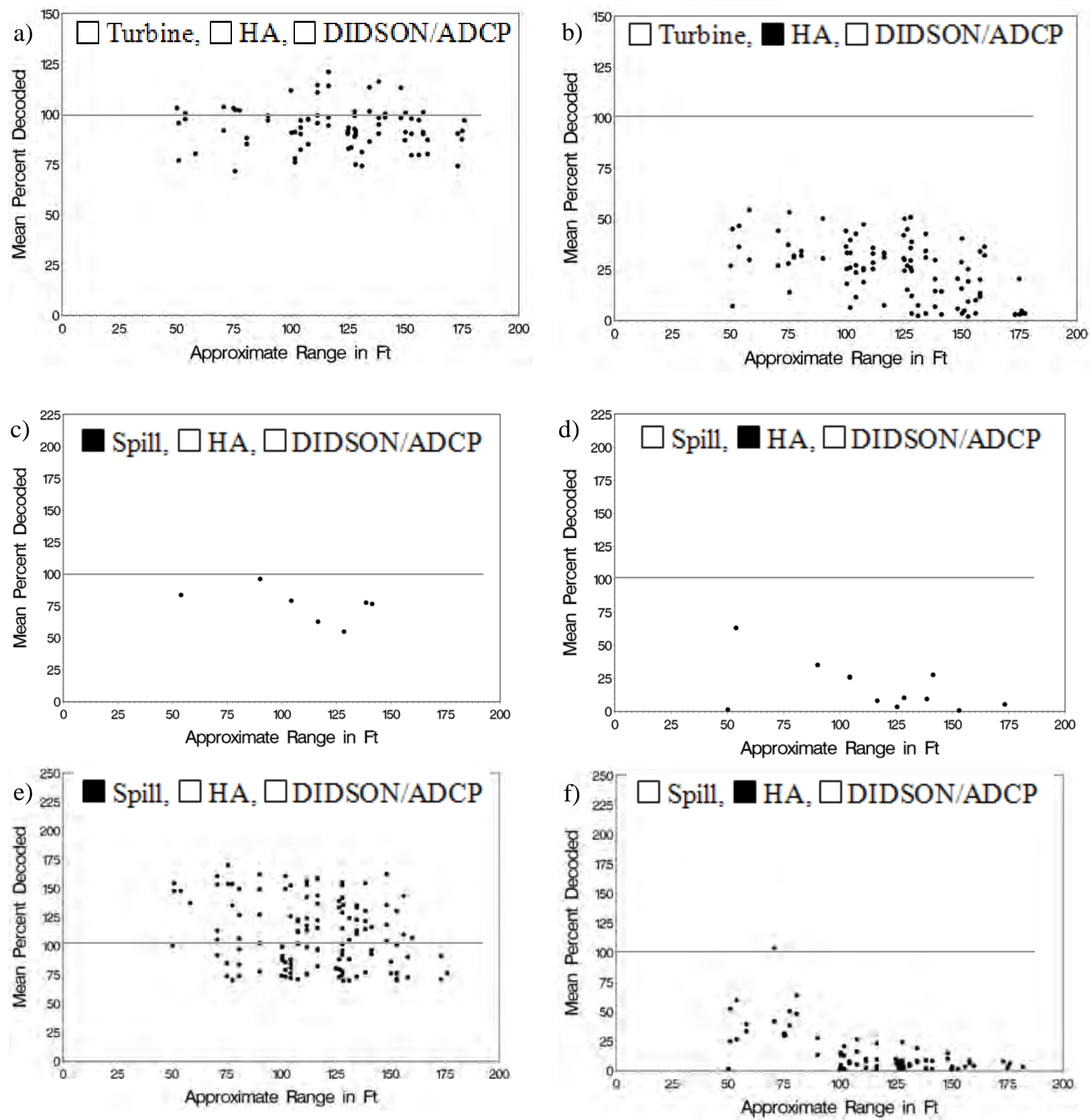

Figure 3.7. PAS Hydroacoustic System Operations, DIDSON/ADCP Off, Plywood Baffle. (a) Turbine hydroacoustics off, typical SC hydrophone; (b) turbine hydroacoustics on, old hydrophone; (c) spillway hydroacoustics off, old hydrophone; (d) spillway hydroacoustics on, old hydrophone; (e) spillway hydroacoustics off, 180-degree hydrophone; (f) spillway hydroacoustics on, 180-degree hydrophone.

Only one out of four hydroacoustic-on treatments had significantly lower percentage decoded than the five hydroacoustic-off treatments for the JSATS mobile hydrophone (Figure 3.8). The JSATS mobile hydrophone uses different processing algorithms and filters that appear to be less affected by short hydroacoustic pulses than the JSATS cabled node detector. 


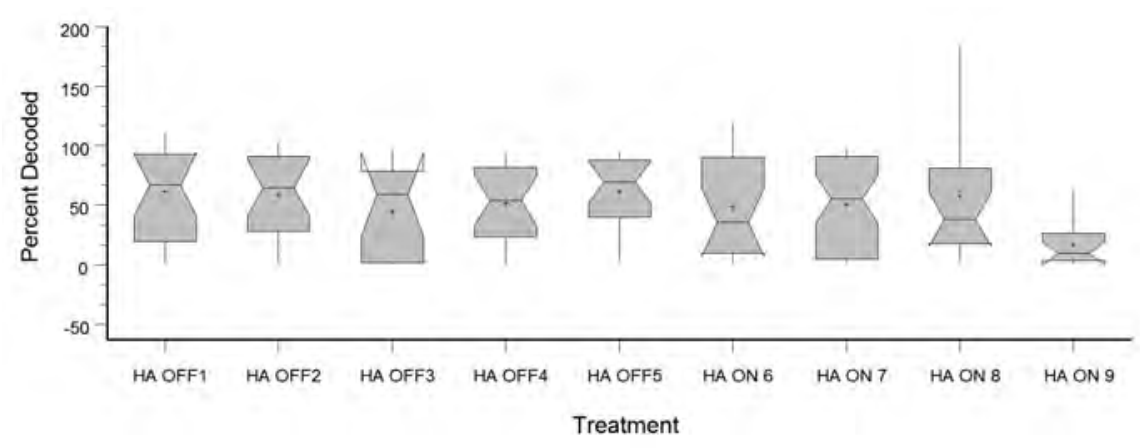

Figure 3.8. Summary Data from JSATS Mobile Node, Sonics Concepts Hydrophones with JSATS Detectors and Decoders. The "HAOFF" and "HAON" treatments are for various tests when the PAS hydroacoustic system was off and on, respectively. The notches measure the significance of the difference between two medians. The medians are significantly different at approximately the $95 \%$ level if the notches do not overlap.

\subsubsection{PAS Hydroacoustic System Transmit Level}

The MPD decreased as hydroacoustic transmit level increased from -12 to $-10 \mathrm{~dB}$, although there was little difference at levels over $-10 \mathrm{~dB}$ (Figure 3.9). The data combined across JSATS transmitters showed there was a decrease in MPD from 100\% to $80 \%$ when the PAS system transmitted at the $-12 \mathrm{~dB}$ transmission level (Figure 3.9). When transmit level was increased to $-11 \mathrm{~dB}$, the MPD decreased to $30 \%$. For transmission levels from $-10 \mathrm{~dB}$ to $-6 \mathrm{~dB}$, the MPD was about $15 \%$.

This trend of decreasing decode performance with increasing transmit level was observed for each of the 15 individual JSATS tags studied (Figure 3.10a-3.10o). Rates of decline varied with the detectability of tags when the hydroacoustic system was off (arbitrarily assigned to a $-15 \mathrm{~dB}$ transmission level in Figure 3.10).

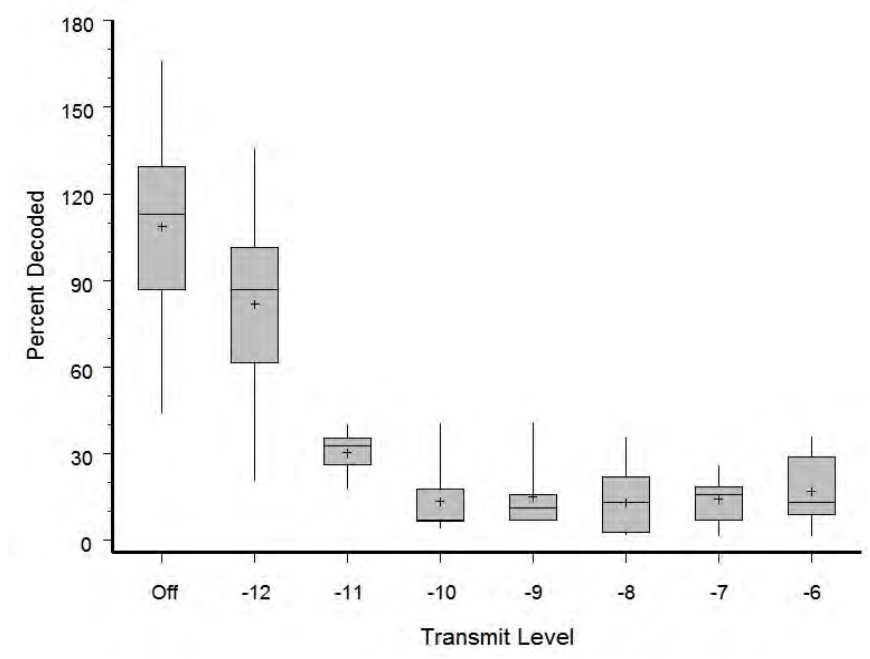

Figure 3.9. Relationship Between Mean Percentage Decoded and PAS Hydroacoustic Transmit Level (dB). Bars represent the ranges of data; boxes denote the 25th and 75th percentiles; the middle lines are the medians; and the plus signs are the means. 

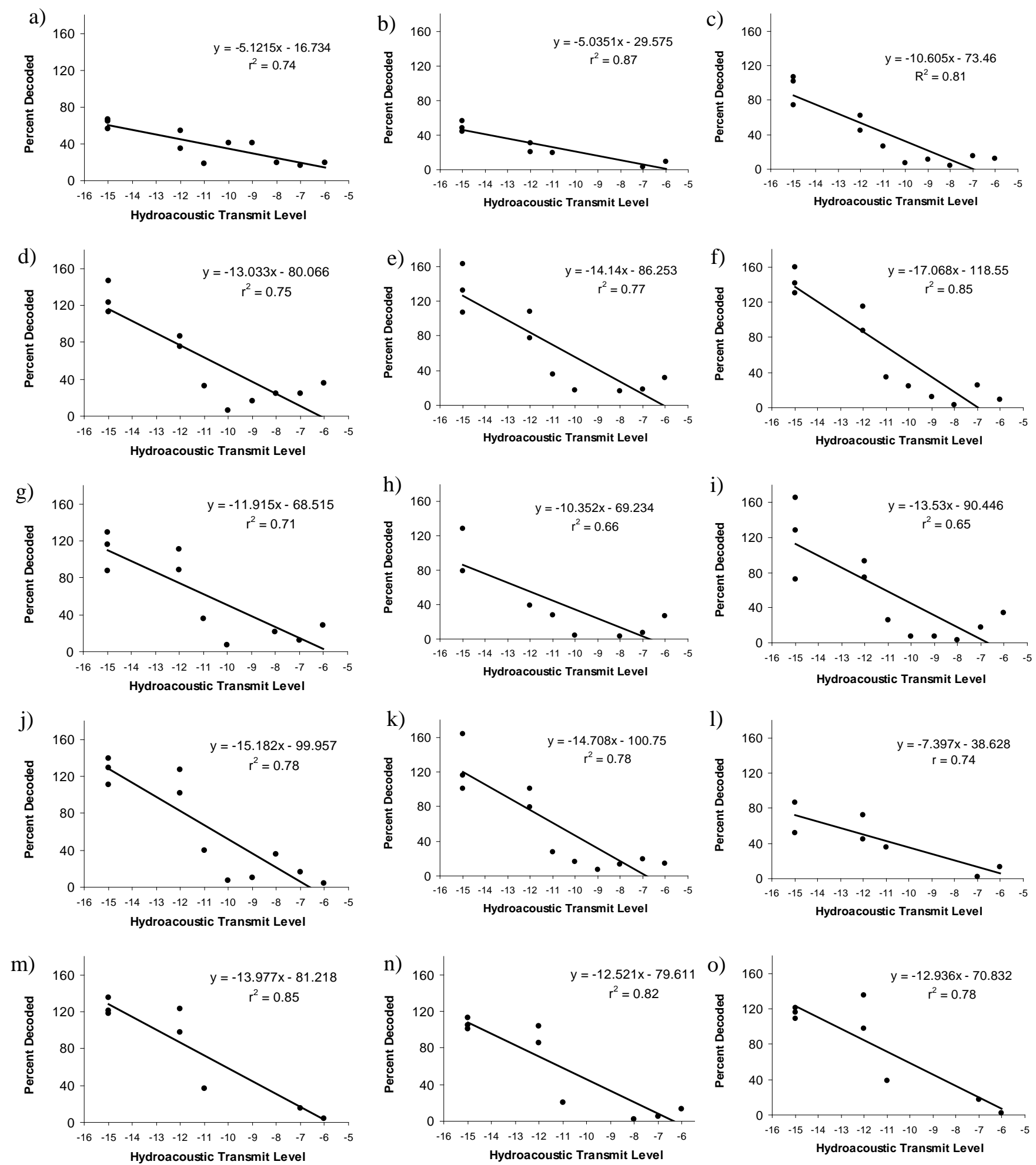

Figure 3.10. Relationship Between MPD and PAS Hydroacoustic Transmit Level. Each panel contains data for one JSATS transmitter. Each point is the average percent decoding by multiple hydrophones from the spillway and baffling on individual hydrophones. Transmit level $15 \mathrm{~dB}=$ hydroacoustic system off. 


\subsection{Discussion and Conclusions}

This report described the acoustic optimization study conducted during January and February 2008 at John Day Dam. The study provided valuable insight into how to sample concurrently with multiple underwater acoustic systems. The optimization process, though, is necessarily ongoing because hydrophone baffling, acoustic detection software, and decoding software are continually improving. Therefore, results presented in this study represent a worst-case examination of concurrent sampling of multiple acoustic technologies that is dated by the development stage of the equipment and software used during the study. PNNL plans further field tests of the effects of hydroacoustic transmit levels on the latest version of the JSATS detector during the hydroacoustic study scheduled for October to December 2008 at The Dalles Dam.

Optimization can be achieved by limiting interference to acoustic telemetry systems through several approaches, including: 1) placing hydrophones upstream of other sound sources and baffling to protect them from sounds echoing from the downstream direction; 2) reducing sound transmission levels from active sources; and 3) improving discrimination of acoustic tag detection software against active hydroacoustic signals. PNNL pursued all of these approaches in the study reported herein.

Based on the findings from the optimization study, we concluded that there was no appreciable adverse effect on mean percentage of JSATS transmissions decoded from

- turbine operations

- spillway operations

- DIDSON/ADCP acoustic energy

- PAS hydroacoustic systems at transmit level of $-12 \mathrm{~dB}$, although there was a significant impact at all higher transmit levels (-11 to $-6 \mathrm{~dB})$.

The optimization study showed that, if the goal of a particular acoustic telemetry study is to determine route of passage and consequently estimate passage efficiencies and route-specific survival rates, then operating fixed-aspect hydroacoustic systems at a $-12 \mathrm{~dB}$ transmit level should not have a measurable negative effect on detection of transmissions from JSATS tags in a forebay. However, when spatially accurate 2-D or 3-D tracking is required to assess fish behavior, it would be wise to not allow other sound sources so that all tag transmissions within range of the hydrophones have the highest potential to be detected and decoded. Fortunately, by the very nature of most hydroacoustic sampling at dams, there are blocks of sanctuary times during which hydroacoustic transducers are off. Typical hydroacoustic sampling is sequential with sampling only occurring on an individual transducer 12.5 to $25 \%$ of the time; the other 75 to $87.5 \%$ of the time that transducer is off while sampling occurs at other locations. For example, an echosounder sampling transducers in eight turbines or spill bays only transmits in one of the locations every eight minutes; thus each location sampled is quiet for 7 out of 8 minutes.

The main conclusion from this optimization study is that valid JSATS telemetry data can be collected simultaneously with a DIDSON/ADCP and a PAS hydroacoustic system at transmit level of -12 dB. Multiple evaluation tools should be considered to increase the robustness and thoroughness of future fish passage evaluations at John Day and other dams. 


\subsection{Literature Cited}

Johnson, GE, F Khan, JB Hedgepeth, RP Mueller, CL Rakowski, MC Richmond, JA Serkowski, and JR Skalski. 2006. Hydroacoustic Evaluation of Juvenile Salmonid Passage at The Dalles Dam Sluiceway, 2005. PNNL-15540, prepared by the Pacific Northwest National Laboratory, Richland, Washington for the U. S. Army Corps of Engineers, Portland District, Portland, Oregon.

Johnson, GE, MC Richmond, JB Hedgepeth, GR Ploskey, MG Anderson, Z Deng, F Khan, RP Mueller, CL Rakowski, NK Sather, JA Serkowski, and JR Steinbeck. 2008. Smolt Responses to Hydrodynamic Conditions in Forebay Flow Nets of Surface Flow Outlets, 2007. PNNL-17387, prepared by the Pacific Northwest National Laboratory, Richland, Washington for the U. S. Army Corps of Engineers, Portland District, Portland, Oregon.

Ploskey GR, CB Cook, PS Titzler, RA Moursund. 2002. Optimization of Hydroacoustic Deployments at John Day Dam. PNNL-14062, prepared by the Pacific Northwest National Laboratory, Richland, Washington for the U. S. Army Corps of Engineers, Portland District, Portland, Oregon.

Ploskey, GR, MA Weiland, CR Schilt, J Kim, PN Johnson, ME Hanks, DS Patterson, JR Skalski, and JB Hedgepeth. 2005. Hydroacoustic Evaluation of Fish Passage Through Bonneville Dam in 2004. PNNL15249, by the Pacific Northwest National Laboratory, Richland, Washington for the U. S. Army Corps of Engineers, Portland District, Portland, Oregon. 



\section{Distribution}

No. of PDF

Copies

1 Robert Wertheimer

U.S. Army Corps Of Engineers

P.O. Box 2946

Portland, OR 97208
No. of PDF

Copies

15 Internal Distribution

Pacific Northwest National Laboratory

P.O. Box 999

Richland, WA 99352

Carlson

BPO

Choi

Cushing

Dauble

Deng

Fischer

Johnson

Khan

Kim

LaMarche

McMichael

Ploskey

Weiland

Wilberding

Zimmerman
K8-91

NBON

K6-85

K9-33

NBON

BPO

K6-85

NBON

K8-91

K6-85

NBON

NBON

NBON

NBON 


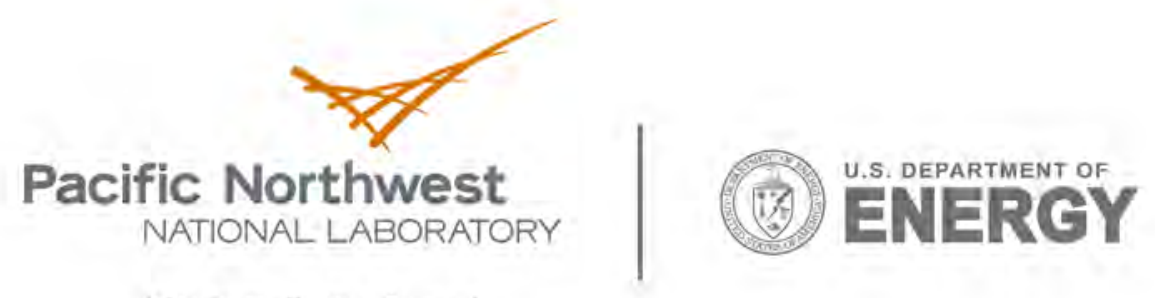

902 Battelle Boulevard

P.O. Box 999

Richland, WA 99352

1-888-375-PNNL (7665)

www.pnl.gov 